\title{
Do Risk-Taking Incentives Induce CEOs to Invest? New Evidence from Acquisitions
}

\author{
Ettore Croci and Dimitris Petmezas*
}

May 2013

\begin{abstract}
This paper examines the effect of risk-taking incentives on acquisition investments. We provide evidence that high vega CEOs are more likely to invest in acquisitions. Economically, an inter-quartile range change in vega translates into an approximately $6 \%$ enhancement in acquisition investments. Further, the association between risk-taking incentives and acquisition investments is generally not affected by several corporate governance mechanisms. Moreover, risk-taking incentives do not promote internal investments. Finally, bidders with high vega CEOs generate relatively larger acquisition announcement returns. Overall, the results are consistent with the theory that high risk-taking incentives induce CEOs to undertake investments.
\end{abstract}

JEL Classification: G34; M12

Keywords: Executive Compensation; Managerial Incentives; Risk-Taking; Mergers and Acquisitions

\footnotetext{
*Ettore Croci is from the Department of Economics and Business Administration, Università Cattolica del Sacro Cuore, Milan, Italy, E-mail: ettore.croci@unicatt.it. Dimitris Petmezas is from Surrey Business School, University of Surrey, UK, E-mail: d.petmezas@surrey.ac.uk. We would like to thank George Alexandridis, Lorenzo Caprio, François Derrien, Alex Edmans, Mara Faccio, Miguel Ferreira, Andrey Golubov, Halit Gonenc, Paul Guest, Nikolaos Karampatsas, Christos Mavis, Alain Schatt and seminar participants at the University of Bologna, University of Bristol and University of Neuchâtel for helpful comments and suggestions. All remaining errors are our own.
} 
Mergers and Acquisitions (M\&As) represent major corporate investments with CEOs receiving, very often, lucrative compensation packages (Grinstein and Hribar 2004). Yet, acquisition projects are also investments under uncertainty, which may, to an extent, alter firm's status quo and increase managerial risk (Datta, Iskandar-Datta, and Raman 2001). Recent empirical evidence (Conyon, Core, and Guay 2011; Fernandes et al. 2013) highlights that CEOs are not prone to accept risk without being properly compensated. In fact, they receive higher pay when the risk associated to executive compensation is relatively higher. Building on this insight, the objective of this study is to investigate whether high risk-taking incentives induce CEOs to conduct acquisition investments.

Following the seminal work on agency theory by Jensen and Meckling (1976), there has been a continuous debate on how firm investment opportunity set, driven by manager's ability to influence future cash flows risk, is related to CEOs compensation package structure. A central principle of the principal-agent theory is the positive association between risk and incentives (Holmström and Milgrom 1987); in particular, higher performance pay induces greater effort from the agents but increases the risk on their compensation. In this respect, the sensitivity of CEO wealth to stock price (first moment), called delta in the literature, appears to align managers and shareholders' interests (Jensen and Murphy 1990). Nevertheless, at the same time delta increases managers' exposure to risk, which might prevent CEOs to undertake some positive NPV projects when they are very risky. Smith and Stulz (1985) argue that shareholders can reduce managers' risk aversion to risky but valuable investment projects by increasing the convexity of the relation between managers' wealth and firm performance. Given that option-based contract plans increase significantly the convexity of managerial compensation (Guay 1999), CEOs with high risk-taking incentives have a stronger motivation than their counterparts to invest in order to maximize shareholder wealth. Therefore, the sensitivity of CEO wealth to firm stock return volatility (second moment), 
which we refer to hereafter as vega, may induce risky investment choices by CEOs who seek to benefit from an increase in share price volatility. The recent theoretical framework of Edmans and Gabaix (2011) predicts that risk-averse CEOs are offered compensation contracts with greater risk-taking incentives, which induce them to take on high risk projects. This is also consistent with Lewellen, Loderer, and Martin's (1987) findings, which suggest that managerial risk aversion may be reduced by the increased use of equity-based remuneration. ${ }^{1}$ Overall, the aforementioned discussion raises the following questions regarding the relationship of executive risk-taking incentives and acquisition investments: Do high risk-taking incentives induce CEOs to take the risk to carry out an acquisition deal? What is the relationship between bidding firm CEO risk-taking incentives and acquisition announcement returns?

Motivated by the relationship between managerial incentive plans and firm investment policy, in this paper we address these questions and test the role of option-based plans particularly vega controlling also for delta ${ }^{2}-$ in the context of M\&As, a major corporate event. As Harford and Li (2007) argue, acquisition decisions may be the most important corporate resource allocation decisions that CEOs take. Using M\&As to investigate the relationship between incentive contracts and risk-taking behavior is of paramount interest for three main reasons: First, given the well-documented presence of substantial agency conflicts in M\&As (Jensen 1986; Lewellen, Loderer, and Rosenfeld 1985; Morck, Shleifer, and Vishny 1990), corporate takeovers serve as an ideal testing platform to explore the relation between managerial risk-taking incentives and investment decisions. Particularly, increases in risk-linked compensation are also in line with the agency theory, which suggests that optimal CEO compensation should align the interests of risk-averse managers with those of

\footnotetext{
${ }^{1}$ Lewellen Loderer, and Martin (1987) posit that offering high stock-based remuneration raises the cost to the manager of variance reducing projects, whereas it boosts the rewards for variance increasing projects.

${ }^{2}$ Guay (1999) suggests that the mix of vega and delta varies to a great extent across firms and both affect risktaking behavior. Therefore, in order to draw fruitful conclusions with regards to the relation between vega and acquisition investments, we should also control for delta.
} 
shareholders by motivating managers to commit to risk-increasing projects (Jensen and Meckling 1976; Smith and Stulz 1985). Second, M\&As are perhaps the largest and possibly the riskiest investments decided by CEOs. While many acquisitions add value for acquiring firm shareholders, including CEOs with equity-based compensation, a significant fraction turn out poorly. ${ }^{3}$ Third, studying M\&As allows to explore the effect of pay incentives on risk-taking behavior - at least partially - easing concerns regarding reverse causality. ${ }^{4}$ Given that our main variable of interest is the sensitivity of CEO wealth accumulated over time to the stock return volatility, it is most likely that making an acquisition in year $t$ does not drive vega in year $t-1$, which mitigates a potential concern of reverse causality.

The empirical literature has well established that acquisitions increase firm risk. ${ }^{5}$ For instance, Datta, Iskandar-Datta, and Raman (2001) provide evidence that acquirers with relatively higher equity-based compensation exhibit greater changes in stock return standard deviation post-acquisition; Bargeron et al. (2012) find that acquisition announcements are associated with an increase in bidder implied volatility; and Furfine and Rosen (2011) and Hagendorff and Vallascas (2011) show that a merger increases acquirer default risk. Therefore, this increase in risk indicates that ceteris paribus CEOs should be less prone to conduct an M\&A investment. However, if risk-averse CEOs are offered option-based contracts, which provide them with greater risk-taking incentives, they are more likely to get

\footnotetext{
${ }^{3}$ It is worth noting that more than US public acquisitions are associated, on average, with negative acquiring firm announcement returns (Moeller, Schlingemann, and Stulz 2004); nevertheless, almost half of the deals (42\%) are positive NPV investment projects for a sample of acquisitions over the period 1992-2006. (The Boston Consulting Group, July 2007).

${ }^{4}$ Guay (1999) and Tchistyi, Yermack, and Hun (2011) show that stock-return volatility is positively associated with CEO wealth sensitivity and option-based contracts, respectively; nevertheless, in this case, the possibility of reverse causality is hard to exclude. Regressing measures such as stock return volatility on incentive compensation appears to create problems of reverse causality. In fact, one could argue that regressing stock return volatility in year $t$ on incentive compensation in year $t-1$ induces risk-taking because the former preceded the latter. Nevertheless, it may be that stock return volatility in year $t-1$ causes both; perhaps, stock return volatility in year $t-1$ causes incentive compensation in year $t$ - 1 (i.e., reverse causality from stock return volatility to risk-taking incentives), and stock return volatility in year $t$ - 1 causes stock return volatility in year $t$.

${ }^{5}$ There is also an alternative view that particularly conglomerate acquisitions generally lead, through the diversification effect, to reduced risk for the combined entity (Amihud and Lev 1981).
} 
induced to undertake high risk projects. Therefore, we predict that high executive risk-taking incentives provoke CEOs to undertake acquisition investments.

We use a sample of US acquisitions over the period from 1997 to 2011 and find strong support to our conjectures. As a preliminary step, we show, consistent to the prior literature, that, indeed, acquisitions increase firm risk. Post- or around the event stock (excess) return volatility of firms involved in acquisitions is significantly higher than their pre-announcement stock (excess) return volatility. Next we find, controlling for the effect of other factors known to affect the decision to carry out an acquisition investment, that CEO vega is positively associated to the M\&A investment at the $1 \%$ significance level. To gauge the economic significance of these estimates, an inter-quartile range change in vega boosts acquisition investments by approximately 6\%. This is consistent with Edmans and Gabaix (2011) theoretical model of CEOs being offered greater risk-taking incentives for high risk investments.

We also perform the following empirical tests. We first test the role of several corporate governance mechanisms in the relationship between risk-taking incentives and M\&A investments. We document that vega coefficient itself remains positive and significant while its interaction with several corporate governance characteristics appears not to have, in general, any effects on CEO pay incentives to conduct an M\&A investment. In particular, we find that only the interaction of dual-class shares with vega is negative and marginally significant at the $10 \%$ level. Overall, the results on the effect of corporate governance mechanisms indicate that the existence of these control enhancing devices do not weaken the relationship between high CEO risk-taking incentives and acquisition investments.

Moreover, we examine the relationship of vega with the propensity of a lower risk investment, namely internal investment (i.e., CAPEX and unexpected CAPEX investments), as proposed by Harford and Li (2007). We find that risk-taking incentive carries, a non- 
positive coefficient at conventional levels in all specifications (it is negative and strongly significant at the $1 \%$ significance level in regressions of unexpected CAPEX investment). In economic terms, an inter-quartile range change in vega reduces CAPEX investment by more than $10 \%$. This result, coupled with the relationship of vega with acquisition investments, implies that the effect of risk-taking incentives on external investments (i.e., acquisitions), which are associated with greater uncertainty, is substantially more pronounced than its effect on internal investments. In fact, this represents a re-allocation of investment dollars to riskier assets reinforcing the theoretical predictions of Edmans and Gabaix (2011) model.

Additionally, we pursue three different approaches to ease concerns regarding endogeneity. Following Coles, Daniel, and Naveen (2006), i) we use the predicted estimates of lagged vega and delta; and ii) to reduce the likelihood of reverse causality, we perform systems of simultaneous equations. In particular, we run three-stage least squares (3SLS) regressions, in which the jointly determined variables are the acquisition investments, vega and delta. Third, to further eliminate concerns regarding endogeneity, we do perform a quasinatural experiment over the recent crisis period, which introduces an exogenous shock to delta and vega. The crisis period allows to overcome the identification challenge by exploiting changes in firm's risk that are exogenous and unanticipated. In all three approaches our main result holds as CEO vega is still positively associated with acquisition investments.

Furthermore, we examine the relationship between the quality of an acquisition around the announcement and CEO vega. We find that CEO vega, which takes into consideration the sensitivity of CEO wealth to stock return volatility, is positively associated with bidder 5-day CARs consistent with Tehranian, Travlos, and Waegelein (1987) and Datta, Iskandar-Datta, and Raman (2001) who examine the relationship of managers' long-term incentive plans and top five executives equity-based compensation contacts (i.e., delta), respectively, with 
acquiring firm announcement returns and also find a positive association. We also show that target status does not affect the association between vega and bidder returns. Overall, the announcement return analysis suggests that CEOs, induced to take risk, carry out acquisition investments that increase their shareholders' wealth.

Finally, we perform three further robustness checks. First, we examine the effect of a change in vega - instead of vega itself - on acquisition investments. The intuition here is that CEOs with a significant increase in vega should be more prone to acquire other companies. Indeed, we find that a change in vega is positively associated with acquisition investments. Second, we analyze acquisition deals involving only public target firms. Golubov, Petmezas, and Travlos (2012) suggest that the reputational exposure risk in M\&As is confined to public deals that are closely followed by the market and often involve publicity as part of the bargaining process. In addition, public deals frequently require regulatory and/or shareholder approvals, which increase complexity, demanding strong CEO skills. Liu and McConnell (2013) also observe that the level and tone of media attention, which is likely to be considerably greater in large public deals than in small private ones, heighten the impact of a value-reducing acquisition on manager's reputational capital. Assuming a link between executive compensation and firm performance, it is particularly in these investments, where we should expect CEOs to have high risk-taking incentives. We provide evidence of a positive relationship between CEO vega and public acquisition investments. Third, we use the vega (and delta) measure of Edmans, Gabaix, and Landier (2009), which is independent of firm size, and our results are robust. In particular, CEO vega is always positively related with both acquisition investments and bidder 5-day CARs.

This study has important contributions to the pay incentive-risk taking and M\&Asexecutive compensation literature. First, it offers empirical evidence to the literature that studies the effect of risk-taking incentives on corporate investments, in the context of M\&As- 
perhaps the most important corporate event. We show a positive relationship between CEOs risk-taking incentives and acquisition investments. Additionally, by incorporating both vega and delta in our empirical analysis, we are able to isolate the effect of each of these incentives on risk-taking. Second, it provides new evidence that the association between risk-taking incentives and acquisition investments is generally not affected by several corporate governance mechanisms, apart from dual-class shares but only marginally. Third, it offers new insights to the existing literature on the relationship between CEO compensation and bidding firm shareholder value creation: we reveal that CEO risk-taking incentives increase acquiring firms' shareholders wealth and this relationship stands irrespective of the target public status. This result implies that CEO risk-taking incentives lead them to select investment opportunities of relatively better quality.

Our study is related to the work of Lewellen, Loderer, and Martin (1987), Tehranian, Travlos, and Waegelein (1987), Guay (1999), Datta, Iskandar-Datta, and Raman (2001), Grinstein and Hribar (2004), Coles, Daniel, and Naveen (2006), Harford and Li (2007) and Edmans and Gabaix (2011). Grinstein and Hribar (2004) examine the relationship between CEO pay and completion of M\&A deals measuring compensation with cash bonus at the end of the acquisition year. We measure CEO pay with option-based contracts (i.e., risk-taking incentives) prior to the year of the acquisition. Harford and $\mathrm{Li}$ (2007) document that compensation changes after external investments are much larger than after internal investments. Our paper shows the relationship between pre-event risk-taking incentives and external versus internal investments, highlighting that risk-taking pay incentive has a considerably more profound effect in acquisitions rather than CAPEX investments. Tehranian Travlos, and Waegelein (1987) and Datta, Iskandar-Datta, and Raman (2001) examine within a sample of public acquisitions the effect of managers' long-term incentive plans and top five executives equity-based compensation contacts (i.e. delta), respectively, on acquiring firm 
announcement returns. We uncover the effect of CEO risk-taking incentives (i.e., vega) and find a similar association with bidder announcement returns. Coles, Daniel, and Naveen (2006) suggest that high-risk taking CEO compensation is associated with riskier investment policy. We provide evidence of higher risk-taking incentives in the M\&A investments setting. Overall, the findings of this study are consistent with the predictions of the theoretical model of Edmans and Gabaix (2011) and the empirical findings of Lewellen, Loderer, and Martin (1987) and Guay (1999), when applied in the context of M\&As.

The rest of the paper is organized as follows. Section I discusses the relevant literature. Section II describes our sample and the variables used in the empirical analysis. Section III examines the effect of executive risk-taking incentives on i) acquisition investments considering also several corporate governance mechanisms; and ii) CAPEX and unexpected CAPEX investments. Section IV deals with endogeneity issues. Section V examines the association between the quality of acquisitions and CEO vega. Section VI provides some further robustness checks. Finally, Section VII concludes the paper.

\section{Related Literature}

\subsection{Theoretical and empirical framework}

Holmström and Milgrom (1987) show, by maximizing the objective function of the principal subject to the participation and incentive compatibility constraints of the agent, that the optimal compensation scheme is a linear function of the risk involved. In addition, a recent theoretical work on the relationship between risk-taking and incentives by Edmans and Gabaix (2011) proposes a model in which risk-averse CEOs receive higher pay incentives for undertaking a risky positive NPV project, contrary to traditional models, which assume exogenous risk and predict a negative relationship. In particular, they argue that when CEOs are more risk-averse or the firm is riskier, it is essential to offer them even more convexity to 
induce them to undertake a value-increasing risky investment. The authors conclude by stating that there is a positive relation between incentives and the marginal increase in risk caused by value-enhancing actions, which has both cross-sectional and time-series implications.

Empirically, turning to the investment policy, Coles, Daniel, and Naveen (2006) attempt, by estimating a system of simultaneous equations, to solve the potential causal effect of pay incentives on corporate risk-taking. The authors provide evidence that high risk-taking CEO compensation induces a riskier investment policy. Particularly, vega is positively (negatively) associated with investment in $\mathrm{R} \& \mathrm{D}$, focus on a small number of businesses and leverage (investment in property plant and equipment). Additionally, in a recent paper, Gormley, Matsa, and Milbourn (2013) find, using a natural experiment of an increase in liability and regulatory risk from workers' exposure to newly identified carcinogens of 143 US firms over the period 1984-2008, that CEOs with lower risk-taking incentives reduce firm leverage, $R \& D$ and stockpile cash and conduct more diversifying acquisitions.

\subsection{Executive compensation and M\&As}

In the M\&A related studies, there is evidence that executive compensation may lead to less than optimal merger outcomes. For instance, previous studies provide evidence of special benefits and/or increased compensation irrespective of merger success paid to acquiring firm CEOs (Bliss and Rosen 2001; Grinstein and Hribar 2004) and target firm CEOs (Hartzell, Ofek, and Yermack 2004). Grinstein and Hribar (2004) find that CEOs who have more power to influence board decisions receive significantly larger cash bonuses post-deal. In addition, the authors report a positive association between bonus compensation and measures of effort, but not between bonus compensation and deal performance. 
Furthermore, Tehranian, Travlos, and Waegelein (1987) show that acquiring firms with long-term performance plans experience higher abnormal stock returns at the acquisition announcement relative to acquirers without these plans. Similarly, Datta, Iskandar-Datta, and Raman (2001) document a positive relationship between acquiring firm top five executives' equity-based pay, measured as a percentage of total compensation paid to them, and acquiring firm stock returns around and following public acquisition announcements. Finally, Harford and Li (2007) suggest that pay practices that supplement cash compensation with incentive pay plans provide incentives to CEOs to carry out acquisitions as their postacquisition total compensation, with the exception of the best-governed firms, increases substantially irrespective of the merger performance. The study also provides evidence that pay changes after large internal investments are much smaller than after acquisitions.

\section{Data and Methodology}

\subsection{Sample statistics}

Our sample consists of all NYSE, AMEX, and NASDAQ firms jointly listed on the COMPUSTAT ExecuComp Database, the COMPUSTAT annual industrial files, and the CRSP files from 1996 through 2010. Our sample is composed of 3,177 firms for a total of 30,702 firm/year observations. ${ }^{6}$ Acquisition data are obtained from Thomson Financial SDC Mergers and Acquisitions Database and include all acquisitions by US publicly listed bidding firms over the period 1997 to 2011 with a deal value above \$1 million. To be included in the acquisition sample, the acquirer must own less than $10 \%$ of the target's equity before the deal and must seek to purchase more than $90 \%$ of the target's equity. After matching the two samples, we find that 2,056 acquirers (6,587 firm-year observations) conducted 9,789

\footnotetext{
${ }^{6}$ Excluding firms from financial industries (SIC codes 6000-6999) does not alter our main results. Specifically, 546 sample firms are from financial industries (4,390 firm/year observations). These firms carried out 1,556 acquisitions during our sample period.
} 
acquisitions over the period 1997 to 2011 , out of which 9,003 are completed. ${ }^{7}$ Table 1 presents the sample of acquisitions. On average, acquisitions of private targets represent the $78.47 \%$ of the entire M\&A activity in our sample. Additionally, target firm is on average $12.70 \%$ the size of bidder, but the relative size of the (average) acquisition varies greatly across the sample period.

\section{[Please Insert Table 1 About Here]}

Coles, Daniel, and Naveen (2006) review prior empirical evidence on executive compensation measures and argue that they were, at the very best, noisy proxies for delta and vega. Hence, as the authors highlight, the estimation of vega and delta for the manager's entire portfolio leads to a more precise CEO measure of incentives than relying on potentially noisy proxies such as the number or value of options or stock held or granted. Therefore, we estimate delta, which is the dollar change in CEO wealth for a $1 \%$ change in stock price, and vega, which is the change in the dollar value of the executive's wealth for a $1 \%$ change in the annualized standard deviation of stock returns. The vega and delta calculations follow Guay (1999) and Core and Guay (2002), ${ }^{8}$ who use the Black-Scholes (1973) option valuation model as modified by Merton (1973) to account for dividends. Guay (1999) shows that option vega is many times higher than stock vega. Consequently, to conform with prior literature (Knopf, Nam, and Thornton 2002; Rajgopal and Shevlin 2002; Coles, Daniel, and Naveen 2006), we use the vega of the option portfolio to measure the total vega of the stock and option portfolios. We also compute the measure of delta suggested by Edmans, Gabaix, and Landier (2009), which scales the dollar change in CEO wealth for a percentage change in

\footnotetext{
${ }^{7}$ The remaining acquisitions are pending (460), intended (8), partially completed (4), and withdrawn (314). Our main results hold when we limit the sample to completed deals.

${ }^{8}$ See Edmans, Gabaix, and Landier (2009) for a detailed description of the computation of delta and vega. We assume that the maturity of all options is $70 \%$ of the stated maturity. Results do not change if we relax this assumption.
} 
firm value by the CEO's annual pay. We label this variable Delta EGL. ${ }^{9}$ Similarly, we also calculate Vega EGL. As emphasized by Edmans, Gabaix, and Landier (2009), these measures are independent of firm size.

Table 2, Panel A reports descriptive statistics for CEO pay, breaking down total compensation into cash compensation (salary plus bonus), equity compensation, CEO wealth and CEO incentive measures. CEO compensation figures are obtained from ExecuComp database. We winsorize all our non-binary variables at the $1^{\text {st }}$ and $99^{\text {th }}$ percentile. All dollar values are stated in 2005 dollars.

Equity based compensation is on average more than $72 \%$ of the total compensation (\$3.427mil./\$4.784mil.), and option compensation represents a large fraction of equity based compensation (\$2.311mil.). Delta and vega are not based merely on the annual compensation, but they depend on the wealth that a CEO has accumulated over time in the forms of stock and stock option grants. The value of the CEO wealth, given by the sum of the stock and option portfolios, is on average above $\$ 66 \mathrm{mil}$., with most of the value sourcing from the stock portfolio (about $\$ 55 \mathrm{mil}$.). The mean (median) delta is approximately $\$ 842,000(\$ 234,000)$, and the mean (median) vega is $\$ 130,000(\$ 47,000)$. These values are larger than those reported by Coles, Daniel, and Naveen (2006), a finding that is plausible considering that our executive compensation sample period terminates in 2010 and equity compensation increased sharply between 2005 and $2010 .^{10}$

\section{[Please Insert Table 2 About Here]}

Figure 1 shows the evolution of vega and delta over time for our sample. Noticeably, vega tripled from 1995 to 2003 followed by a decline until 2008. However, after the crisis of 2008 vega rose again in years 2009 and 2010. Delta displays an increase until the late 90s;

\footnotetext{
${ }^{9}$ Our values for Delta EGL are similar to those of $\mathrm{B}^{\mathrm{I}}$ from Edmans, Gabaix, and Landier (2009), available at https://finance.wharton.upenn.edu/ aedmans/data.html. Minor differences arise from the estimation of the inputs of the option pricing formula.

${ }^{10}$ Kaplan (2012) documents that average CEO pay has not continued to increase since the large run up of the 1990 s, but pay-for-performance remains very high.
} 
however it drops sharply until 2002, then being relatively stable until 2007 and falling sharply again in 2008. Nevertheless, similarly to vega, delta rebounded in 2009 and 2010.

[Please Insert Figure 1 About Here]

\subsection{Variables}

In our empirical analysis, we control for the following variables that have been found in the prior literature to be correlated with the propensity of an acquisition investment. All variables are defined in Appendix A. We use the log of sales, ln (sales), as a proxy for size conforming to the common practice of the CEO literature (see, e.g., Hall and Murphy 2002; Conyon, Core, and Guay 2011; Fernandes et al. 2013). Sales represent firm's total sales in year $t$. Harford (1999) and Faccio and Masulis (2005) find that large firms carry out more acquisitions.

Book-to-Market $(\mathrm{b} / \mathrm{m})$ is firm book value of equity divided by market value of equity at the end of year $t$ from COMPUSTAT. According to the market-driven theory of acquisitions (Shleifer and Vishny 2003), firms make more acquisitions when their stock is overvalued.

Cash reserves variable is defined as firm cash and short-term investments divided by the book value of total assets at the end of the fiscal year. Cash-rich firms are relatively more likely to engage in acquisitions (Jensen 1986), as also empirically documented by Harford (1999) and Faccio and Masulis (2005).

Leverage represents firm total financial debt (long-term debt plus debt in current liabilities) divided by the book value of total assets at the end of the fiscal year. Leverage has competing effects on the propensity to acquire. On the one hand, leverage can increase the likelihood of becoming a bidder by inducing firms to take on risky investments; on the other hand, an excessive debt level may reduce the ability to acquire by exhausting new debt issuing capacity. While Harford (1999) finds no evidence that leverage affects the probability 
to buy other firms, Faccio and Masulis (2005) document a positive relation between leverage and the propensity of an acquisition. Uysal (2011) observes that overleveraged firms are less likely to carry out acquisitions.

Cash flows variable, as used in Titman, Wei, and Xie (2004), is defined as (operating income before depreciation minus interest expenses minus taxes minus preferred dividends minus common dividends) scaled by book value of total assets in the fiscal year, and it is our proxy for firm's internally generated funds. ${ }^{11}$ Firms generating high levels of internal cashflows are less constrained in their investment policies, thus increasing the likelihood of an acquisition (Bauguess and Stegemoller 2008).

We also control for CEO overconfidence by constructing an overconfidence variable which is based on the Holder 67 measure of Malmendier and Tate $(2005,2008)$. In the spirit of Hirshleifer, Low, and Teoh (2012), overconfidence is a binary variable that takes the value of one when a CEO fails to exercise options with five years remaining duration despite a stock price increase of at least $67 \%$ since the grant date, and zero otherwise. Differently from Malmendier and Tate $(2005,2008)$, where once a CEO is identified as overconfident, she remains so for the rest of the sample period, we measure overconfidence on a yearly basis. ${ }^{12}$ As noted by Malmendier, Tate, and Yan (2011) and Hirshleifer, Low, and Teoh (2012), ExecuComp does not provide detailed data on the CEO's options holdings and exercise prices for each option grant for our entire sample period. To overcome this problem, we follow Campbell et al. (2011) and Hirshleifer, Low, and Teoh (2012) in calculating an average moneyness of the CEO's option portfolio for each year. First, for each CEO-year, we divide the total realizable value of the options by the number of options held by the CEO to determine the average realizable value per option. The strike price is calculated as the fiscal

\footnotetext{
${ }^{11}$ Cash flows variable is highly correlated with ROA (0.85). Thus, we do not include the profitability variable, which is defined as firm EBITDA divided by its book value of total assets at the fiscal year-end from COMPUSTAT, in our regression models.

${ }^{12}$ Treating overconfidence as a managerial fixed-effect as in Malmendier and Tate $(2005,2008)$ does not alter our results.
} 
year-end stock price minus the average realizable value. The average moneyness of the options is then calculated as the stock price divided by the estimated strike price minus one. Only the vested options held by the CEO are included in the computation. Malmendier and Tate (2008) argue that overconfident managers are more acquisitive.

We also include in our analysis other CEO-specific variables, which are obtained from the ExecuComp database and proxy for managerial risk aversion and entrenchment. Specifically, we include cash compensation, CEO gender (female) and tenure (CEO tenure). Cash compensation and female proxy for risk aversion of the manager. The direction of the effect of cash compensation is far from straightforward. On the one hand, Guay (1999) posits that CEOs with higher total cash compensation are better diversified, as they have more money to invest outside the firm, and, therefore, are less risk averse. On the other hand, Berger, Ofek, and Yermack (1997) argue that CEOs with higher cash compensation are more likely to be entrenched and will seek to avoid risk. With regards to the gender, Barber and Odean (2001) suggest that male investors are more risk-prone and overconfident than female investors. ${ }^{13}$ Additionally, CEO tenure is a proxy for managerial entrenchment. Longertenured CEOs have usually more power than newly-appointed CEOs, and they can exert this power embarking in acquisition programs. CEO gender and tenure have also been found to be correlated with the probability to win awards. In particular, Malmendier and Tate (2009) provide evidence that more experienced and female CEOs are more likely to enjoy "superstar" status. Furthermore, Malmendier and Tate (2009) find that superstar CEOs receive larger pay than non-superstar CEOs.

The final set of variables takes into account several corporate governance characteristics at firm level. Bauguess and Stegemoller (2008) show that corporate governance characteristics affect the decision to acquire, providing evidence consistent with

\footnotetext{
${ }^{13}$ However, Ahern and Dittmar (2012) find that an increase in female directors leads to more acquisitions in Norway.
} 
benefits to managerial initiative when managers are insulated from discipline, i.e., more value-increasing acquisitions. Data for the corporate governance variables are from RiskMetrics. Our set of corporate governance variables is composed of five variables: entrenchment index, DCS, independent board, CEO/Chairman and board size. Entrenchment index is an index proposed by Bebchuk, Cohen, and Ferrell (2009), which contains a subset of the provisions included in the G Index of Gompers, Ishii, and Metrick (2003). ${ }^{14}$ The index is the sum of binary variables concerning the following provisions: 1) classified boards; 2) limitations to shareholders' ability to amend the bylaws; 3) supermajority voting for business combinations; 4) supermajority requirements for charter amendments; 5) poison pills; and 6) golden parachutes. DCS is a binary variable that takes the value of one if the firm is a dualclass shares company, and zero otherwise. The dual class structure allows controlling shareholders to separate control from ownership, effectively controlling the company with a lower percentage of cash flows rights. Masulis, Wang, and Xie (2009) find that executives related to the controlling shareholder in DCS firms receive higher total compensation than those in firms with single class shares, a result consistent with the managerial power theory (Bebchuk and Fried 2003). We measure the independence of the board of directors with independent directors, which is the ratio between the number of independent directors and the board size. A CEO is more powerful and entrenched when he/she is also Chairman of the board of directors. CEO/Chairman is a binary variable that takes the value of one if the roles of CEO and Chairman of the Board are not split, and zero otherwise. Board size is the number of directors of the board. Bauguess and Stegemoller (2008) report that acquisitions are more likely to occur when firms have large boards.

\footnotetext{
${ }^{14}$ We use the entrenchment index and not the $\mathrm{G}$ index because, after 2006, Riskmetrics stopped providing the $\mathrm{G}$ index and data concerning some of the provisions that compose the $\mathrm{G}$ index. Data for the $\mathrm{G}$ index are available up to 2006. We rerun our analysis with the G Index instead of the entrenchment index for the subsample up to 2006. We do not observe any significant change in the results.
} 
Panel B reports summary statistics on firm and CEO characteristics. Concerning CEO characteristics, the average tenure is more than 6.5 years, with a median of 5 years. Thus, the average CEO has been with the company for a relatively long time, and therefore its delta and vega are functions of the wealth accumulated over this long period. Very few companies are run by female CEOs (only 2\%), and about half of the CEOs are overconfident (47\%). The percentage of independent directors is well-above $50 \%$ (i.e., 68.7\%), which is in line with Duchin, Matsusaka, and Ozbas (2010). Confirming previous literature (for instance, Ferris, Pritchard, and Jagannathan 2003; Duchin, Matsusaka, and Ozbas 2010), the average board is composed of about 9.5 directors. The CEO retains also the title of Chairman of the board in $55.27 \%$ of the observations. Finally, firms with a dual-class share structure are about $9 \%$, which is higher than the $6 \%$ found by Masulis, Wang, and Xie (2009) for the entire universe of COMPUSTAT listed firms.

In the next section we run a multivariate analysis to examine the relationship between vega (and delta) with acquisition investments. The correlation matrix of the above variables is presented in Appendix B. Our main variable of interest - vega - does not exhibit high correlation with the control variables. This should moderate econometric difficulties (such as multicollinearity concerns) in disentangling any effects of the compensation variables on acquisition investments.

\section{Empirical Analysis}

\subsection{Acquisitions and change in firm risk}

Our premise that high risk-taking incentives induce CEOs to conduct an M\&A investment is based on the notion that acquisitions are risk-increasing corporate investments. Whereas Datta, Iskandar-Datta, and Raman (2001), Bargeron et al. (2012), Furfine and Rosen (2011) and Hagendorff and Vallascas (2011) have already provided evidence in support of firm risk 
increase after acquisitions, we still investigate, before analyzing the relationship between risk-taking incentives and acquisition investments, whether indeed acquisitions increase firm risk in our sample. We therefore examine the change in the bidder standard deviation of daily (excess) stock returns in two ways: i) we measure the difference between the bidder standard deviation of daily (excess) stock returns over the period 60 days to 120 days after the acquisition announcement and the one over the period 120 days to 60 days prior to the event; and ii) we measure the difference between the bidder standard deviation of daily (excess) stock returns over the event window $(-30,+30)$ surrounding the acquisition announcement and the one over the period 120 days to 60 days prior to the event.

Table 3 reports the results. Very briefly, the difference between bidder post- as well as around the acquisition announcement volatility and bidder pre-acquisition volatility is positive and strongly statistically significant in both mean and median terms for both stock return volatility and excess stock return volatility. Overall, the results signify that acquisitions increase firm risk and are therefore risky investments.

\section{[Please Insert Table 3 About Here]}

\subsection{Risk-taking incentives and acquisition investments}

After establishing that acquisitions are risky investments, we examine the relation between risk-taking incentives and acquisition investments by controlling for various characteristics, which have been found in the prior literature to affect acquisition investments. ${ }^{15}$ Table 4 reports the results for this analysis. In specifications (1) and (2) we run pooled tobit regressions where the dependent variable is the sum of the deal values of acquisitions made in a given year scaled by firms' total sales in the previous year. To mitigate endogeneity concerns, all independent variables, including vega and delta, are lagged. All regressions also

\footnotetext{
${ }^{15}$ The advantage of tobit analysis compared to probit is that it overcomes the problem of several acquisitions being small relative to bidder size in our sample. However, we still perform probit analysis in the robustness checks section (Section VI.A.) and find similar results.
} 
control for year and industry fixed effects whose coefficients are suppressed. Moreover, we use heteroskedasticity-robust standard errors adjusted also for clustering at firm level.

Our main variable of interest is the sensitivity of CEO wealth to stock return volatility (i.e. vega). Specification (1) also includes delta and several control variables, such as size, $\mathrm{b} / \mathrm{m}$, cash reserves, leverage, cash flows, overconfidence and cash compensation. We find that the coefficient on vega is positive and statistically significant at the $1 \%$ significance level. From the control variables, delta, cash reserves, cash flows, overconfidence and cash compensation exhibit a positive relationship with acquisition investments at conventional significance levels, while $\mathrm{b} / \mathrm{m}$ has a negative association with acquisition investments at the $1 \%$ significance level in line with the existing M\&A literature. Specification (2) includes further explanatory variables, namely female and CEO tenure. Again, vega is strongly positively associated with acquisition investments at the $1 \%$ significance level. From the control variables, CEO tenure carries a negative coefficient significant at the $1 \%$ and all other explanatory variables show exactly the same relationship with acquisition investments as in specification (1).

In specifications (3) and (4), instead of using a tobit model, we run pooled probit regressions where the dependent variable takes the value of one if the firm made at least one acquisition in a given year over the period between January 1, 1997 and December 31, 2011, and zero otherwise. Our results are robust to the methodology employed as in both specifications vega carries a positive and significant coefficient at the $1 \%$ level. The signs on the control variables exhibit, in general, the same relationship as in specifications (1) and (2). These findings imply that risk-taking incentives increase the probability a CEO to carry out an acquisition deal.

In economic terms, an inter-quartile change in vega from the $25^{\text {th }}$ to the $75^{\text {th }}$ percentile boosts acquisition investments by approximately $6 \%$ respectively. This percentage change in 
acquisition investments is calculated as the difference between the fitted value of acquisition investments, with vega measured at its $75^{\text {th }}$ percentile, and the fitted value of an acquisition with vega measured at its $25^{\text {th }}$ percentile, divided by the latter value. ${ }^{16}$ Overall, our results support Edmans and Gabaix (2011) theoretical model which predicts higher risk-taking incentives for high risk investments.

[Please Insert Table 4 About Here]

\subsection{The role of corporate governance}

In this section, we examine whether corporate governance mechanisms affect risk-taking incentives for acquisition investments. One could argue that effective corporate governance might mitigate $\mathrm{CEO}$ risk-taking incentives in the fear of potential value destructive investments at the expense of firm shareholders. Table 5 presents the results for this tobit analysis where the dependent variable is again the sum of the deal values of acquisitions made in a given year scaled by firms' total sales in the previous year. In total, we include five corporate governance variables in our regressions; namely entrenchment index, independent directors, DCS, board size and CEO/Chairman. The main variable of interest is again vega. We also interact vega (and delta) with all five governance variables and incorporate all other control variables used in Table 4.

We find that vega coefficient is always positive and statistically significant at conventional levels. This indicates that risk-taking incentives provoke CEOs to carry out (public) M\&A investments. With regards to the interaction of vega with corporate governance characteristics, there is a marginal effect of its interaction only with $D C S$. More specifically, the interaction of DCS with vega is negative and significant at the $10 \%$ significance level in specification (3), indicating that the existence of this control enhancing

\footnotetext{
${ }^{16}$ To compute these fitted values, all other control variables are fixed at their mean values.
} 
device alleviates the impact of CEO risk-taking incentives on acquisition investments. The signs on other explanatory variables are similar to previous analysis. In sum, the findings of this section reflect that risk-taking incentives which may induce CEOs to conduct M\&A investments are generally not affected by several corporate governance mechanisms.

[Please Insert Table 5 About Here]

\subsection{Risk-taking incentives and CAPEX investments}

Our main argument, based on the theoretical predictions of Edmans and Gabaix (2011) model, is that risk-averse CEOs are offered compensation contracts with greater risk-taking incentives inducing them to take on high risk projects. If this is the case, then lower risk projects should, in turn, be associated with lower CEO risk-taking incentives. In this respect, Andrade and Stafford (2004) argue that there are important differences between internal and external investments. The authors posit that M\&As, as in the case of internal investments, facilitate firm growth, but only M\&As appear to make possible industry contraction. Moreover, they observe that merger clustering by industry suggests that these deals are often a response to industry shocks. In line with Andrade and Stafford (2004), Harford and Li (2007) provide evidence that CEOs treat internal investments differently and that the uncertainty and information environment surrounding an acquisition allow the CEO more leeway in arguing for downside protection. Therefore, instead of merely examining the relationship between risk-taking incentives and external investments (i.e., acquisitions), we follow Harford and Li (2007) and conduct further analysis on a sample of firms that made internal investments (i.e., capital expenditures).

Table 6 reports the results. In specifications (1) and (2) we present the estimates of OLS regressions with clustered standard errors at firm level where the dependent variable is the 
CAPEX (capital expenditures) investments scaled by total assets. ${ }^{17}$ In specifications (3) and (4) we conform to the CAPEX definition of Titman, Wei, and Xie (2004) and Harford and Li (2007) in order to have similar size-enlarging corporate actions; we run pooled probit regressions where the dependent variable is the unexpected CAPEX investments, which is a binary variable that takes the value of one if the difference between CAPEX in year $t$ and the average CAPEX in years $t-1, t-2$, and $t-3$ is larger than $10 \%$ of the firm's sales at the end of year $t-1$, and zero otherwise from COMPUSTAT. The control variables are similar to the ones used in Table 4. Interestingly, in specifications (1) and (2) vega is statistically insignificant at conventional levels. In specifications (3) and (4) vega is negatively associated with the probability of a large unexpected CAPEX investment at the $1 \%$ significance level. These results indicate that large internal investments do not increase with risk-taking incentives. Economically, an inter-quartile range change in vega leads to a decrease of a large unexpected CAPEX investment by more than $10 \%$. Our findings on CAPEX analysis provide evidence that risk-taking incentives have a substantially lower effect (and even inverse for unexpected CAPEX) on internal investments, which are characterized by lower risk, than external investments (i.e., acquisitions), representing a re-allocation of investment dollars to riskier assets. Overall, the results reinforce the theoretical predictions of the Edmans and Gabaix (2011) model.

[Please Insert Table 6 About Here]

\footnotetext{
${ }^{17}$ Our results are similar when using pooled tobit regressions. The use of OLS in CAPEX analysis is justified by the fact that firms usually make a positive investment in CAPEX every year, which alleviates the censoring problem that led us to run tobit analysis for acquisition investments in previous sections.
} 


\section{Endogeneity Issues}

\subsection{Predicted values of vega and delta}

In this section, we further examine whether vega induces managers to implement acquisition investments by reporting estimates from regressions of all acquisition investments on lagged vega, lagged delta and contemporaneous control variables (same as in the main analysis). In particular, we use either the lagged values of vega and delta or the vega and delta predicted from the regressions as instruments for vega and delta. We include our endogeneous variables (i.e., acquisition investments) on the right hand side. We calculate the predicted values of lagged vega and lagged delta for a firm in a given year by using the estimated regression coefficients. Residual lagged vega (or lagged delta) is the actual minus the predicted value.

Table 7 presents the results. We find that predicted vega is positive and significant at 1\%. In specifications (2) and (4) we use the predicted and residual incentives from regressions of vega and delta on endogenous and control variables. Again, the predicted vega carries a positive and statistically significant coefficient at the $1 \%$ level supporting our previous findings. Finally, we find that the predicted vega coefficient does not have the same sign with the residual vega coefficient, which implies that the components of vega and delta that are orthogonal to the other right-hand side variables do not have explanatory power. Additionally, given that the predicted vega is included on the right hand side, the insignificant or negative coefficients on residual vega values is a first indication that there is no causation flowing the other direction (Coles, Daniel, and Naveen 2006).

[Please Insert Table 7 About Here] 


\subsection{Systems of simultaneous equations (3SLS): Acquisition investments, vega and delta}

So far our analysis was based on the notion that risk-taking incentives and acquisition investments are jointly determined. However, parameter estimates from tobit regressions are likely to be biased when the regressors are endogeneously determined along with the dependent variable. To alleviate concerns that our results are driven by causality we apply a simultaneous equations approach as in Coles, Daniel, and Naveen (2006).

Table 8 shows the results for the systems of simultaneous equations analysis. More specifically, we run three-stage least squares (3SLS) regressions in which the jointly determined variables are all acquisition investments, vega and delta. We have the same independent variables as in previous analysis for the all acquisition investments model and we follow Coles, Daniel, and Naveen (2006) for the vega and delta models. A requirement in systems of simultaneous equations is to use contemporaneous rather than lagged values of independent variables; hence, all our independent variables, including vega and delta, are contemporaneous. The regressors for vega are acquisition investments, delta, size, $\mathrm{b} / \mathrm{m}$, leverage, cash flows, cash compensation, CAPEX, annualized excess return volatility and EBITDA/interest expenses. The regressors for delta are acquisition investments, vega, size, b/m, leverage, female, CAPEX and annualized excess return volatility.

Importantly, vega is positive and strongly significant at the $1 \%$ significance level. This indicates a strong positive association between vega and acquisition investments. With regards to the control variables, they are consistent to the analysis in previous sections and to the prior literature. Similarly, the determinants of delta and vega are generally in line with previous research. In a nutshell, our results are robust controlling for potential reverse causality reflecting that risk-taking incentives provoke CEOs to undertake acquisition investments. 


\subsection{Quasi-natural experiment: Crisis period}

To further eliminate the likelihood that our results are spurious, and to isolate the effects of risk-taking incentives on acquisition investments and of acquisition investments on risktaking incentives, we use a quasi-natural experiment. In particular, we examine the relationship between vega (and delta) and acquisition investments in the recent crisis period, which introduces an exogenous shock to vega and delta. Using a quasi-natural experiment serves to overcome concerns regarding the suitability of instruments by exploiting changes in firm's risk that are exogenous and unanticipated. Given that the incentive effects of a manager's overall portfolio of options and stocks are often slow to respond to the change in risk environment, the crisis period serves as an ideal setting to examine how CEOs respond to an increase in firm's unanticipated risk as a function of their pre-existing incentive contracts. The unanticipated change in firm's risk environment allows us to exclude the possibility of reverse causality between these pre-determined incentives and subsequent risk-taking CEO behavior.

Table 9 presents the results. We offer two approaches for the crisis period. First, we run tobit regressions in specification (1) for the next year (i.e., 2009) and in specification (2) for the next two years (i.e., 2009 and 2010). Our main variable of interest, vega, as well as all other control variables (used in the main analysis of Table 4) are of the year 2008. Interestingly, vega is positively associated with acquisition investments after 2008 in both specifications. It is significant at the $1 \%$ level for the next year and at the $5 \%$ level for the next two years. Second, we use an instrumental variable approach as in Dittmar and Ahern (2012) to examine the effect of vega on the propensity to make acquisition investments after the financial crisis. In particular, we instrument vega (and delta) using the pre-crisis vega 
(delta) interacted with year dummies. ${ }^{18}$ This approach is based on the assumption that firms have different vega but the crisis increases volatility and exogenously changes vega. As already shown in Figure 1, there was an increase in vega (and delta) after 2008. Nevertheless, the degree to which firm vega (and delta) is affected by the crisis depends on its pre-crisis level, hence the instrument. We report the second-stage regression in which instrumented vega is again positive and statistically significant at the $5 \%$ level. Overall, our results for the crisis period provide further evidence to the argument that risk-taking incentives induce CEOs to conduct acquisition investments.

[Please Insert Table 9 About Here]

\section{Risk-Taking Incentives and Acquisition Quality}

In this section, we address the question of whether CEO risk-taking pay incentive plans (i.e., vega) lead to larger bidding firm announcement returns. Prior studies provide evidence that, in general, top executive incentive plans (i.e., delta) have a positive relationship with acquiring firm announcement stock returns (see, e.g., Tehranian, Travlos, and Waegelein 1987; Datta, Iskandar-Datta, and Raman 2001). Our main dependent variable is the acquirer 5-day CAR surrounding the acquisition announcement. The returns are calculated using the market model with the market model parameters estimated over the period starting 240 days and ending 41 days prior to the announcement. CRSP value-weighted index return is the market return. ${ }^{19}$ Our main variable of interest is again vega controlling also for delta. We use the same set of explanatory variables used in previous analysis including also the variables relative size, diversifying, completed, hostile, tender offer, public, return volatility and stock

\footnotetext{
${ }^{18}$ In the first stage regression, we regress vega (delta) on year dummies and the interaction of year dummies with the pre-crisis vega (delta), i.e. vega (delta) in 2007, including also firm fixed effects.

${ }^{19} \mathrm{We}$ also use alternative short-run announcement period return windows such as $(-1,+1)$ and $(-5,+5)$; we use equally-weighted CRSP index (as opposed to value-weighted) as the market return; iii) we use market-adjusted abnormal returns (i.e., assuming $\alpha=0$ and $\beta=1$ as market model parameters); iv) we winsorize the returns at the 1 st and 99 th, or 5 th and 95 th percentiles to control for outliers. None of these variations change our results.
} 
which have been found by prior studies to affect bidder announcement returns. Relative size is the ratio between the deal value and the market capitalization of the bidding firm 30 days prior to the acquisition announcement. Diversifying is a dummy variable that takes the value of one if the target firm operates in the same 4-digit SIC industry as the one of the bidder, and zero otherwise. Completed is also a dummy variable that takes the value of one if the deal is completed, and zero otherwise. Hostile is a binary variable that takes the value of one for deals defined as "hostile" or "unsolicited" by Thomson Financial SDC, and zero otherwise. Tender offer is a dummy variable that takes the value of one for tender offers, and zero otherwise. Public is a binary indicator taking the value of one for acquisitions of public targets, and zero otherwise. Annualized return volatility is the standard deviation of bidder stock returns over the year prior to the acquisition. Finally, stock is a binary variable taking the value of one for acquisitions in which the means of exchange was $100 \%$ stock, and zero otherwise.

Table 10 reports the results for acquisition quality. Vega is always positive and strongly statistically significant at the $1 \%$ level. This finding implies that CEO risk-taking incentive pay plans are related with an increase in bidding firm shareholders' wealth. The signs on the control variables are, generally, consistent to the prior M\&A literature. For instance, size, cash reserves, relative size, public and stock hold a negative and statistically significant coefficient at conventional levels, whereas, delta and completed (the latter in specification (3)), are positively associated with bidder announcement returns.

Further, in Panel B we perform the same analysis using the interaction of vega with public to examine whether target status affects the relationship between vega and bidder acquisition announcement returns. We find that vega itself is still positive and statistically significant at the 5\% significance level, whereas the interaction of vega with public is always insignificant at conventional levels. In sum, this positive relationship between risk-taking 
incentives and bidder stock returns allows us to conclude that CEOs with higher risk-taking incentives select investment opportunities of relatively better quality in line with the theoretical predictions of Edmans and Gabaix (2011).

[Please Insert Table 10 About Here]

\section{Further Robustness Checks}

\subsection{Acquisition investments and change in risk-taking incentives}

To further confirm that risk-taking incentives increase acquisition investments, we use as main variable of interest the change in vega instead of vega itself. This allows us to test whether a discrete and significant increase in vega induces more acquisition investments. The change in vega is a binary variable that takes the value of one if the difference between vega in year $t$ and vega in year $t-1$, scaled by vega in year $t-1$, is larger than $10 \%$ and zero otherwise. ${ }^{20}$ Accordingly we define the change in delta. Table 11 present the results. Our results show a strong positive association at the $1 \%$ level between the change in vega (and change in delta) and acquisitions, which adds further evidence to our prior findings that an increase in risk-taking incentives induces CEOs to conduct acquisition investments.

\section{[Please Insert Table 11 About Here]}

\subsection{Risk-taking incentives and public acquisition investments}

For robustness reasons, we further analyze the proposition that risk-taking incentives induce CEOs to undertake high risk investment initiatives. This is particularly the case in acquisitions of public target firms, which arguably entail high reputational exposure risk (Golubov, Petmezas, and Travlos 2012; Liu and McConnell 2013). Therefore, we look into the relation between vega and public acquisition investments. Table 12 reports the results for

\footnotetext{
${ }^{20}$ Similar results are obtained when we increase the cut-off point to $20 \%$.
} 
this analysis. In specifications (1) and (2) we perform pooled tobit regressions and in specifications (3) and (4) we run pooled probit regressions. The explanatory variables are the

same as in Table 4. In specification (1) our main variable of interest, vega, holds a positive and significant coefficient at the 5\% level. This finding implies that, ceteris paribus, CEOs with higher risk-taking incentives are more likely to undertake public acquisition investments, which are related with high reputational exposure risk. All other control variables have the same relationship as in Table 4 with the exception of size which now carries a positive and significant coefficient at the $1 \%$ significance level and delta which is now insignificant at conventional levels. In specification (2), which also includes the female and CEO tenure variables, vega continues to have a positive relationship with public acquisition investments. From the added control variables, CEO tenure variable holds a negative sign. Finally, the results for probit regressions in specifications (3) and (4) show that vega increases the propensity of an acquisition. The signs on the control variables exhibit, in general, the same relationship with acquisition investments as in previous analysis. Overall, these findings imply that risk-taking incentives increase the probability a CEO to carry out an acquisition deal.

[Please Insert Table 12 About Here]

\subsection{EGL measures of incentives}

Finally, as a last robustness check, we examine the relationship of vega (and delta) with acquisition investments and bidding firm 5-day announcement CARs by using the compensation measures proposed by Edmans, Gabaix, and Landier (2009), which are independent of firm size. We label them as vega (EGL) and delta $(E G L)$, respectively.

Table 13 presents the results. In specifications (1) and (2) we run pooled tobit regressions where the dependent variable is the sum of the deal values of acquisitions made 
in a given year scaled by sales in the previous year. We use the same control variables as in Table 4. Vega (EGL) coefficient is positive and statistically significant at the $1 \%$ and $5 \%$ level in specifications (1) and (2), respectively. All other control variables have the same relationship with acquisition investments as in Table 4. Specifications (3) and (4) test the association of vega (EGL) with bidder announcement returns. The control variables are the same used in CARs analysis of Table 10. Again, vega (EGL) increases bidding firm shareholder returns in both specifications. All other explanatory variables are, generally, in line with the M\&A literature. Overall, our findings are robust to the measure of vega and highlight a positive association of vega with both acquisition investments and bidding firm announcement returns.

[Please Insert Table 13 About Here]

\section{Conclusion}

Consistent with the theoretical model of Edmans and Gabaix (2011), which predicts that riskaverse CEOs with greater risk-taking pay incentives are induced to undertake high-risk projects, we find that risk-taking incentives are related with greater acquisition investments. In particular, we provide evidence that higher CEO vega is positively associated with M\&A investments. In economic terms, an inter-quartile range change in vega translates into an approximately $6 \%$ enhancement in acquisition investments.

In addition, this study examines the impact of risk-taking incentives on CAPEX investments. We show that vega has a substantially lower effect (and even inverse) on internal investments (i.e., CAPEX and unexpected CAPEX investments), which are characterized by lower risk, than external investments (i.e., acquisitions), rendering additional support to the theoretical predictions of the relationship between CEO risk-taking incentive plans and investment policy. Addressing the problem of causality through the predicted 
values of lagged vega and delta, systems of simultaneous equations, and a quasi-natural experiment, performing the analysis over the recent crisis period, does not change our main conclusion of the positive association of CEO vega and acquisition investments. Finally, we investigate the effect of CEO vega on bidding firm returns. Interestingly, we find a positive association between CEO risk-taking incentives and bidder announcement returns.

Our findings have also important implications. In particular, higher option-based CEO pay might have led to the increase in the M\&A activity before the recent financial crisis that peaked in 2008. Additionally, the non-positive (in some cases even negative) relationship between vega and CAPEX, coupled with the strong positive association of vega with acquisition investments, implies a re-allocation of firm investment dollars to riskier assets. Finally, the positive effect of executive risk-taking incentives on bidder stock returns provides evidence in support of the view that inducing managers to take on higher risk leads them to select investment opportunities of relatively better quality.

In response to the questions raised in the introduction, the findings of this paper imply that CEO pay incentives-risk taking mechanism does function in firm investment decisions inducing CEOs to undertake risky projects such as acquisitions, in return for higher compensation. Additionally, the link of managerial wealth with firm performance improves CEOs risk-taking investment choices at the benefit of their shareholders. Overall, this paper provides new empirical evidence on the risk taking-investment policy association in the M\&As setting - a major corporate finance topic. 


\section{References}

Ahern, K. R., and A. K. Dittmar. 2012. The Changing of the Boards: The Impact on Firm Valuation of Mandated Female Board Representation. Quarterly Journal of Economics 127: 137-97.

Amihud, Y., and B. Lev. 1981. Risk Reduction as a Managerial Motive for Conglomerate Mergers. Bell Journal of Economics 12: 605-17.

Andrade, G., and E. Stafford. 2004. Investigating the Economic Role of Mergers. Journal of Corporate Finance 10: 1-36.

Barber, B. M., and T. Odean. 2001. Boys will be Boys: Gender, Overconfidence, and Common Stock Investment. Quarterly Journal of Economics 116: 261-92.

Bargeron, L. L., K. Lehn, S. B. Moeller, and F. P. Schlingemann. 2012. Disagreement and the Informativeness of Stock Returns: The Case of Acquisition Announcements. Working Paper, Joseph M. Katz Graduate School of Business, University of Pittsburgh and the Rotterdam School of Management, Erasmus University.

Bauguess, S., and M. Stegemoller. 2008. Protective Governance Choices and the Value of Acquisition Activity. Journal of Corporate Finance 14: 550-66.

Bebchuk, L. A., A. Cohen, and A. Ferrell. 2009. What Matters in Corporate Governance? Review of Financial Studies 22: 783-827.

Bebchuk, L. A., and J. M. Fried. 2003. Executive Compensation as an Agency Problem. Journal of Economic Perspectives 17: 71-92.

Berger, P. G., E. Ofek, and D. L. Yermack. 1997. Managerial Entrenchment and Capital Structure Decisions. Journal of Finance 52: 1411-38.

Bliss, R. T., and R. J. Rosen. 2001. CEO Compensation and Bank Mergers. Journal of Financial Economics 61: 107-38.

Campbell, T. C., M. Gallmeyer, S. Johnson, J. Rutherford, and B. Stanley. 2011. CEO Optimism and Forced Turnover. Journal of Financial Economics 101: 695-712.

Coles, J., N. Daniel, and L. Naveen. 2006. Managerial Incentives and Risk-Taking. Journal of Financial Economics 79: 431-68.

Conyon, M. J., J. E. Core, and W. R. Guay. 2011. Are US CEOs Paid More than UK CEOs? Inferences from Risk-Adjusted Pay. Review of Financial Studies 24: 402-38.

Core, J. E., and W. R. Guay. 2002. Estimating the Value of Employee Stock Option Portfolios and their Sensitivities to Price and Volatility. Journal of Accounting Research 40: 613-30.

Datta, S., M. Iskandar-Datta, and K. Raman. 2001. Executive Compensation and Corporate Acquisition Decisions. Journal of Finance 56: 2299-336. 
Dutchin, R., J. G. Matsusaka, and O. Ozbas. 2010. When are Outside Directors Effective? Journal of Financial Economics 96: 195-214.

Edmans, A., and X. Gabaix. 2011. The Effect of Risk on the CEO Market. Review of Financial Studies 24: 2822-63.

Edmans, A., X. Gabaix, and A. Landier. 2009. A Multiplicative Model of Optimal CEO Incentives in Market Equilibrium. Review of Financial Studies 22: 4881-917.

Faccio, M., and R. W. Masulis. 2005. The Choice of Payment Method in European Mergers and Acquisitions. Journal of Finance 60: 1345-88.

Fernandes, N., M. A. Ferreira, P. Matos, and K. J. Murphy. 2013. Are U.S. CEOs Paid More? New International Evidence. Review of Financial Studies 26: 323-67.

Ferris, S., M. Jagannathan, and A. Pritchard. 2003. Too Busy to Mind the Business? Monitoring by Directors with Multiple Board Appointments. Journal of Finance 58: 1087111.

Furfine, C. H., and R. J. Rosen. 2011. Mergers Increase Default Risk. Journal of Corporate Finance 17: 832-49.

Golubov, A., D. Petmezas, and N. G. Travlos. 2012. When It Pays to Pay Your Investment Banker: New Evidence on the Role of Financial Advisors in M\&As. Journal of Finance 67: 271-312.

Gompers, P., J. Ishii, and A. Metrick. 2003. Corporate Governance and Equity Prices. Quarterly Journal of Economics 118: 107-55.

Gormley, T. A., D. A. Matsa, and T. Milbourn. 2013. CEO Compensation and Corporate Risk-Taking: Evidence from a Natural Experiment. Journal of Accounting and Economics, forthcoming.

Grinstein, Y., and P. Hribar. 2004. CEO Compensation and Incentives: Evidence from M\&A Bonuses. Journal of Financial Economics 73: 119-43.

Guay, W. 1999. The Sensitivity of CEO Wealth to Equity Risk: An Analysis of the Magnitude and Determinants. Journal of Financial Economics 53: 43-71.

Hall, B. J., and K. J. Murphy. 2002. Stock Options for Undiversified Executives. Journal of Accounting and Economics 33: 3-42.

Harford, J. 1999. Corporate Cash Reserves and Acquisitions. Journal of Finance 54: 196997.

Harford, J., and K. Li. 2007. Decoupling CEO Wealth and Firm Performance: The Case of Acquiring CEOs. Journal of Finance 62: 917-49.

Hartzell, J. C., E. Ofek, and D. Yermack. 2004. What's in it for Me? CEOs Whose Firms are Acquired. Review of Financial Studies 17: 37-61. 
Hirshleifer, D. A., A. Low, and S. H. Teoh. 2012. Are Overconfident CEOs Better Innovators? Journal of Finance 67: 1457-98.

Holmström, B., and P. Milgrom. 1987. Aggregation and Linearity in the Provision of Intertemporal Incentives. Econometrica 55: 303-28.

Jensen, M. C. 1986. Agency Costs of Free Cash Flow, Corporate Finance, and Takeovers. American Economic Review 76: 323-29.

Jensen, M. C., and W. H. Meckling. 1976. Theory of the Firm: Managerial Behaviour, Agency Costs and Ownership Structure. Journal of Financial Economics 3: 305-60.

Jensen, M. C., and K. J. Murphy. 1990. Performance Pay and Top-Management Incentives. Journal of Political Economy 98: 225-64.

Kaplan, S. N. 2012. Executive Compensation and Corporate Governance in the U.S.: Perceptions, Facts and Challenges, Working Paper, University of Chicago Booth School of Business and National Bureau of Economic Research (NBER).

Knopf, J. D., J. Nam, and J. H. Thornton Jr. 2002. The Volatility and Price Sensitivities of Managerial Stock Option Portfolios and Corporate Hedging. Journal of Finance 57: 801-13.

Lewellen, W., C. Loderer, and K. Martin. 1987. Executive Compensation Contracts and Executive Incentive Problems: An Empirical Analysis. Journal of Accounting and Economics 9: 287-310.

Lewellen, W., C. Loderer, and A. Rosenfeld. 1985. Merger Decisions and Executive Stock Ownership in Acquiring Firms. Journal of Accounting and Economics 7: 209-31.

Liu, B. and J. J. McConnell. 2013. The Role of the Media in Corporate Governance: Do the Media Influence Managers' Decisions to Abandon Acquisition Attempts? Working Paper, Purdue University.

Malmendier, U., and G. A. Tate. 2005. CEO Overconfidence and Corporate Investment. Journal of Finance 60: 2661-700.

Malmendier, U., and G. A. Tate. 2008. Who Makes Acquisitions? CEO Overconfidence and the Market's Reaction. Journal of Financial Economics 89: 20-43.

Malmendier, U., and G. A. Tate. 2009. Superstar CEOs. Quarterly Journal of Economics 124: 1593-628.

Malmendier, U., G. A. Tate, and J. Yan. 2011. Overconfidence and Early-Life Experiences: The Effect of Managerial Traits on Corporate Financial Policies. Journal of Finance 66: 1687-733.

Masulis, R. W., C. Wang, and F. Xie. 2009. Agency Costs at Dual-Class Companies. Journal of Finance 64: 1697-727. 
Merton, R. C. 1973. Theory of Rational Option Pricing. Bell Journal of Economics and Management Science 4: 141-83.

Moeller, S. B., F. P. Schlingemann, and R. M. Stulz. 2004. Firm Size and the Gains From Acquisitions. Journal of Financial Economics 73: 201-28.

Morck, R., A. Shleifer, and R. W. Vishny. 1990. Do Managerial Objectives Drive Bad Acquisitions? Journal of Finance 45: 31-48.

Rajgopal, S., and T. Shevlin. 2002. Empirical Evidence on the Relation Between Stock Option Compensation and Risk Taking. Journal of Accounting and Economics 33: 145-71.

Shleifer, A., and R. W. Vishny. 2003. Stock Market Driven Acquisitions. Journal of Financial Economics 70: 295-311.

Smith, C., and R. M. Stulz. 1985. The Determinants of Firms' Hedging Policies. Journal of Financial and Quantitative Analysis 20: 391-406.

Tehranian, H., N. G. Travlos, and J. F. Waegelein. 1987. Management Compensation Contracts and Merger-Induced Abnormal Returns. Journal of Accounting Research 25: 5176.

Tchistyi, A., D. Yermack, and H. Yun. 2011. Negative Hedging: Performance Sensitive Debt and CEOs' Equity Incentives. Journal of Financial and Quantitative Analysis 46: 657-86.

The Boston Consulting Group. 2007. The Brave New World of M\&A: How to Create Value from Mergers and Acquisitions.

Titman, S., K. C. J. Wei, and F. Xie. 2004. Capital Investments and Stock Returns. Journal of Financial and Quantitative Analysis 39: 677-700.

Uysal, V. B. 2011. Deviation from the Target Capital Structure and Acquisition Choices. Journal of Financial Economics 102: 602-20. 


\begin{tabular}{|c|c|}
\hline Variable & Definition \\
\hline & Panel A: CEO Compensation Variables \\
\hline Total Compensation & $\begin{array}{l}\text { (ExecuComp data item: TDC1). It includes salary, bonus, total value of restricted stock granted, total value of stock options } \\
\text { granted (using Black-Scholes), and long term incentive payouts in the fiscal year } t-1 \text {. }\end{array}$ \\
\hline Cash Compensation & (ExecuComp data item TCC). It includes salary and bonus in the fiscal year $t-1$. \\
\hline Equity Compensation & The difference between TDC1 and TCC. \\
\hline Option Compensation & $\begin{array}{l}\text { (ExecuComp data item OPTION_AWARDS_BLK_VALUE). The aggregate value of stock options granted to the executive } \\
\text { during the year as valued using Standard \& Poor's Black-Scholes methodology. }\end{array}$ \\
\hline CEO Wealth $(\$ 1,000)$ & The sum of Stock Portfolio and Option Portfolio. \\
\hline Stock Portfolio $(\$ 1,000)$ & $\begin{array}{l}\text { The value of firm's shares at the end of the fiscal year. It is the product of ExecuComp data item SHROWN_EXCL_OPTS } \\
\text { (Shares Owned - Options Excluded) and COMPUSTAT data item PRCC_F (the stock price) at the end of the fiscal year. }\end{array}$ \\
\hline Option Portfolio (\$ 1,000) & $\begin{array}{l}\text { The value of the options held by the CEO at the end of the fiscal year. It is defined as the sum of the estimated value of in- } \\
\text { the-money Unexercised Unexercisable Options (OPT_UNEX_UNEXER_EST_VAL) plus the estimated value of in-the- } \\
\text { money Unexercised Exercisable Options (OPT_UNEX_EXER_EST_VAL). }\end{array}$ \\
\hline Vega & $\begin{array}{l}\text { Vega is the change in the dollar value of the CEO wealth for a one percentage change in the annualized standard deviation of } \\
\text { stock returns at the end of the fiscal year. }\end{array}$ \\
\hline Delta & $\begin{array}{l}\text { The change in the dollar value of the CEO wealth for a one percentage point change in stock price at the end of the fiscal } \\
\text { year. }\end{array}$ \\
\hline Change in Vega & $\begin{array}{l}\text { Binary variable that takes the value of } 1 \text { if the difference between vega in year } t \text { and vega in year } t-1 \text {, scaled by vega in year } t \text { - } \\
1 \text {, is larger than } 10 \% \text {. }\end{array}$ \\
\hline Change in Delta & $\begin{array}{l}\text { Binary variable that takes the value of } 1 \text { if the difference between delta in year } t \text { and delta in year } t-1 \text {, scaled by delta in year } \\
t-1 \text {, is larger than } 10 \% \text {. }\end{array}$ \\
\hline Vega( EGL) & $\begin{array}{l}\text { The dollar change in CEO wealth for a } 1 \% \text { change in the annualized standard deviation of stock returns, scaled by annual } \\
\text { total compensation (ExecuComp data item: TDC1) at the end of the fiscal year. }\end{array}$ \\
\hline Delta (EGL) & $\begin{array}{l}\text { The dollar change in CEO wealth for a } 1 \% \text { change in firm value, scaled by annual total compensation (ExecuComp data } \\
\text { item: TDC } 1 \text { ) at the end of the fiscal year. }\end{array}$ \\
\hline
\end{tabular}




\section{Public Acquisitions}

\section{All Acquisition Investments}

\section{Public Acquisition Investments}

\section{Bidder CARs (-2, 2)}

Stock

\section{Tender Offer}

Private

\section{Relative Size}

Diversifying

Completed

\section{Hostile}

Annualized Return Volatility

Annualized Excess Return Volatility
Binary variable that takes the value of 1 if the firm made at least one acquisition in year $t, 0$ otherwise. The variable is created using data from Thomson Financial SDC.

Binary variable that takes the value of 1 if the firm made at least one public acquisition in year $t, 0$ otherwise. The variable is created using data from Thomson Financial SDC.

It is the sum of the acquisition deal values in year $t$ scaled by firm's sales in year $t-1$. Deal values are from Thomson Financial SDC, firm's sales are from COMPUSTAT.

It is the sum of the public acquisition deal values in year $t$ scaled by firm's sales in year $t-1$. Deal values are from Thomson Financial SDC, firm's sales are from COMPUSTAT.

Cumulative abnormal return for the bidding firm in the 5-day event window $(-2,+2)$ where 0 is the announcement day. The returns are calculated using the market model with the market model parameters estimated over the period starting 240 days and ending 41 days prior to the announcement. CRSP value-weighted index return is the market return.

Binary variable that takes the value of 1 for deals where the method of payment is $100 \%$ stock, 0 otherwise. The variable is created using data from Thomson Financial SDC.

Binary variable that takes the value of 1 for tender offers, 0 otherwise. The variable is created using data from Thomson Financial SDC.

Binary variable that takes the value of 1 if the target firm is a private firm, 0 otherwise. The variable is created using data from Thomson Financial SDC.

It is the ratio between the deal value and the market capitalization of the acquiring firm 30 days prior to the acquisition announcement. Deal value is from Thomson Financial SDC, market capitalization is from CRSP.

Binary variable that takes the value of 1 if the target firm operates in the same 4-digit SIC industry as the one of the bidder, 0 otherwise.

Binary variable that takes the value of 1 if the deal is completed, 0 otherwise. The variable is created using data from Thomson Financial SDC.

Binary variable that takes the value of 1 for deals defined as "hostile" or "unsolicited" by Thomson Financial SDC, 0 otherwise.

It is the standard deviation of bidder stock returns over the year prior to the acquisition.

It is the standard deviation of bidder stock excess returns over the year prior to the acquisition, where excess return is the 
difference of the firm stock return and the CRSP value-weighted index return.

Panel C: Control Variables

$\mathbf{B} / \mathbf{M}$

Cash Reserves

Leverage

Cash Flows

CAPEX

Unexpected CAPEX

Return Volatility

Excess Return Volatility

EBITDA/Interest Expenses

Overconfidence

Female
Log of Sales. Sales represent firm's total sales in the fiscal year from COMPUSTAT.

It is firm book value of equity divided by market value of equity at the fiscal year-end from COMPUSTAT.

It is defined as firm cash and short-term investments divided by the book value of total assets at the fiscal year-end from COMPUSTAT.

It is defined as firm total financial debt (long-term debt plus debt in current liabilities) divided by the book value of total assets at the fiscal year-end from COMPUSTAT.

It is defined as (operating income before depreciation minus interest expenses minus taxes minus preferred dividends minus common dividends) scaled by total assets in the fiscal year from COMPUSTAT.

It is firm's capital expenditures in the fiscal year, scaled by total assets from COMPUSTAT.

It is a binary variable that takes the value of 1 if the difference between firm's capital expenditure (CAPEX) in year $t$ and the average CAPEX in years $t-1, t-2$, and $t-3$ is larger than $10 \%$ of the firm's sales at the end of year $t-1,0$ otherwise. The variable is created using data from COMPUSTAT.

It is the standard deviation of daily stock returns.

It is the standard deviation of daily stock excess returns, where excess return is the difference of the firm stock return and the CRSP value-weighted index return.

It is the interest coverage ratio, calculated as EBITDA divided by interest expenses in the fiscal year from COMPUSTAT.

A CEO is overconfident if she postpones the exercise of vested options that are at least $67 \%$ in the money. Overconfidence is a binary variable that takes the value of 1 when the CEO is identified as overconfident, 0 otherwise. Overconfidence is measured for every sample year. Firstly, for each CEO-year, the total realizable value of the options is divided by the number of options held by the CEO to determine the average realizable value per option. The strike price is calculated as the fiscal year-end stock price minus the average realizable value. The average moneyness of the options is then calculated as the stock price divided by the estimated strike price minus one. Only the vested options held by the CEO are included in the computation.

Binary variable that takes the value of 1 if the CEO is female, 0 otherwise. The variable is created from the field "Gender" in ExecuComp. 


\section{CEO Tenure}

Entrenchment Index

\section{Independent Directors}

\section{DCS}

\section{CEO/Chairman}

Board Size
It is the difference between year $t$ and the year in which the CEO is appointed from ExecuComp.

Bebchuk, Cohen and Ferrell (2009) Entrenchment Index from RiskMetrics. The index is the sum of binary variables concerning the following provisions: 1) Classified boards; 2) Limitations to shareholders' ability to amend the bylaws; 3) Supermajority voting for business combinations; 4) Supermajority requirements for charter amendments; 5) Poison pills; and 6) Golden parachutes.

Percentage of independent directors. It is the ratio between the number of independent directors, and the board size from RiskMetrics.

Binary variable that takes the value of 1 if the firm is a dual-class shares firm, 0 otherwise. The variable is created using data from RiskMetrics.

Binary variable that takes the value of 1 if the roles of CEO and Chairman of the Board are not split, 0 otherwise. The variable is created using data from RiskMetrics.

Number of directors composing the Board of directors from RiskMetrics. 
Appendix B

Variables Correlation Matrix

\begin{tabular}{|c|c|c|c|c|c|c|c|c|c|c|c|c|c|c|c|c|c|}
\hline & 1. & 2. & 3. & 4. & 5. & 6. & 7. & 8. & 9. & 10. & 11. & 12. & 13. & 14. & 15. & 16. & 17. \\
\hline 1. Cash Compensation & 1.00 & & & & & & & & & & & & & & & & \\
\hline 2. Delta & 0.25 & 1.00 & & & & & & & & & & & & & & & \\
\hline 3. Vega & 0.46 & 0.32 & 1.00 & & & & & & & & & & & & & & \\
\hline 4. Delta (EGL) & -0.07 & 0.66 & 0.00 & 1.00 & & & & & & & & & & & & & \\
\hline 5. Vega (EGL) & 0.08 & 0.14 & 0.56 & 0.07 & 1.00 & & & & & & & & & & & & \\
\hline 6. B/M & -0.06 & -0.12 & -0.08 & -0.10 & -0.03 & 1.00 & & & & & & & & & & & \\
\hline 7. Cash Reserves & -0.13 & 0.06 & -0.04 & 0.11 & -0.02 & -0.17 & 1.00 & & & & & & & & & & \\
\hline 8. Leverage & 0.11 & -0.04 & 0.04 & -0.10 & 0.01 & -0.02 & -0.37 & 1.00 & & & & & & & & & \\
\hline 9. Cash Flows & 0.07 & 0.08 & 0.07 & 0.07 & 0.04 & -0.12 & -0.09 & -0.19 & 1.00 & & & & & & & & \\
\hline 10. Size & 0.46 & 0.24 & 0.50 & 0.03 & 0.15 & -0.02 & -0.13 & 0.08 & 0.03 & 1.00 & & & & & & & \\
\hline 11. Female & -0.03 & -0.03 & -0.02 & -0.02 & -0.02 & 0.02 & 0.04 & -0.02 & 0.00 & 0.00 & 1.00 & & & & & & \\
\hline 12. CEO Tenure & 0.03 & 0.23 & 0.02 & 0.23 & 0.05 & 0.00 & 0.03 & -0.05 & 0.05 & -0.06 & -0.04 & 1.00 & & & & & \\
\hline 13. Overconfidence & 0.03 & 0.17 & -0.16 & 0.16 & -0.27 & -0.20 & 0.09 & -0.09 & 0.14 & -0.07 & -0.02 & 0.06 & 1.00 & & & & \\
\hline 14. Entrenchment Index & -0.07 & -0.15 & -0.03 & -0.17 & 0.02 & 0.08 & -0.11 & 0.04 & -0.02 & -0.10 & 0.01 & -0.09 & -0.10 & 1.00 & & & \\
\hline 15. DCS & 0.02 & 0.08 & -0.01 & 0.08 & -0.01 & 0.02 & -0.02 & 0.01 & 0.02 & 0.00 & 0.01 & 0.11 & 0.02 & -0.16 & 1.00 & & \\
\hline 16. Independent Directors & -0.01 & -0.13 & 0.11 & -0.18 & 0.07 & 0.04 & -0.02 & 0.03 & -0.04 & 0.12 & 0.03 & -0.14 & -0.13 & 0.27 & -0.19 & 1.00 & \\
\hline 17. CEO/Chairman & 0.21 & 0.14 & 0.18 & 0.07 & 0.10 & 0.00 & -0.13 & 0.07 & 0.05 & 0.16 & -0.04 & 0.26 & -0.04 & 0.02 & -0.03 & 0.08 & 1.00 \\
\hline 18. Board Size & 0.32 & 0.08 & 0.27 & -0.08 & 0.09 & 0.03 & -0.31 & 0.16 & -0.10 & 0.38 & -0.04 & -008 & -0.07 & 0.09 & 0.00 & 0.08 & 0.11 \\
\hline 19. Excess Return Volatility & -0.22 & -0.08 & -0.20 & 0.00 & -0.16 & 0.04 & 0.28 & -0.03 & -0.23 & -0.19 & 0.03 & -0.03 & -0.02 & -0.02 & 0.00 & -0.15 & -0.12 \\
\hline 20. CAPEX & -0.05 & 0.02 & -0.05 & 0.04 & -0.05 & -0.05 & -0.12 & 0.02 & 0.29 & -0.03 & -0.02 & 0.02 & 0.09 & -0.03 & -0.03 & -0.10 & 0.01 \\
\hline 21. EBITDA/Interest Expenses & -0.07 & 0.05 & -0.03 & 0.10 & 0.00 & -0.09 & 0.26 & -0.30 & 0.21 & -0.07 & 0.01 & 0.06 & 0.08 & -0.04 & 0.02 & -0.05 & -0.04 \\
\hline & 18. & & 19. & & 20. & & & & & & & & & & & & \\
\hline 18. Board Size & 1.00 & & & & & & & & & & & & & & & & \\
\hline 19. Excess Return Volatility & 0.11 & & 1.00 & & & & & & & & & & & & & & \\
\hline 20. CAPEX & -0.12 & & -0.30 & & 1.00 & & & & & & & & & & & & \\
\hline 21. EBITDA/Interest Expenses & 0.01 & & -0.07 & & 0.06 & & & & & & & & & & & & \\
\hline
\end{tabular}

This Appendix presents pairwise Pearson correlations of the variables used in the analysis. All variables are defined in Appendix A. 
Figure 1

Evolution of Vega and Delta Over Time

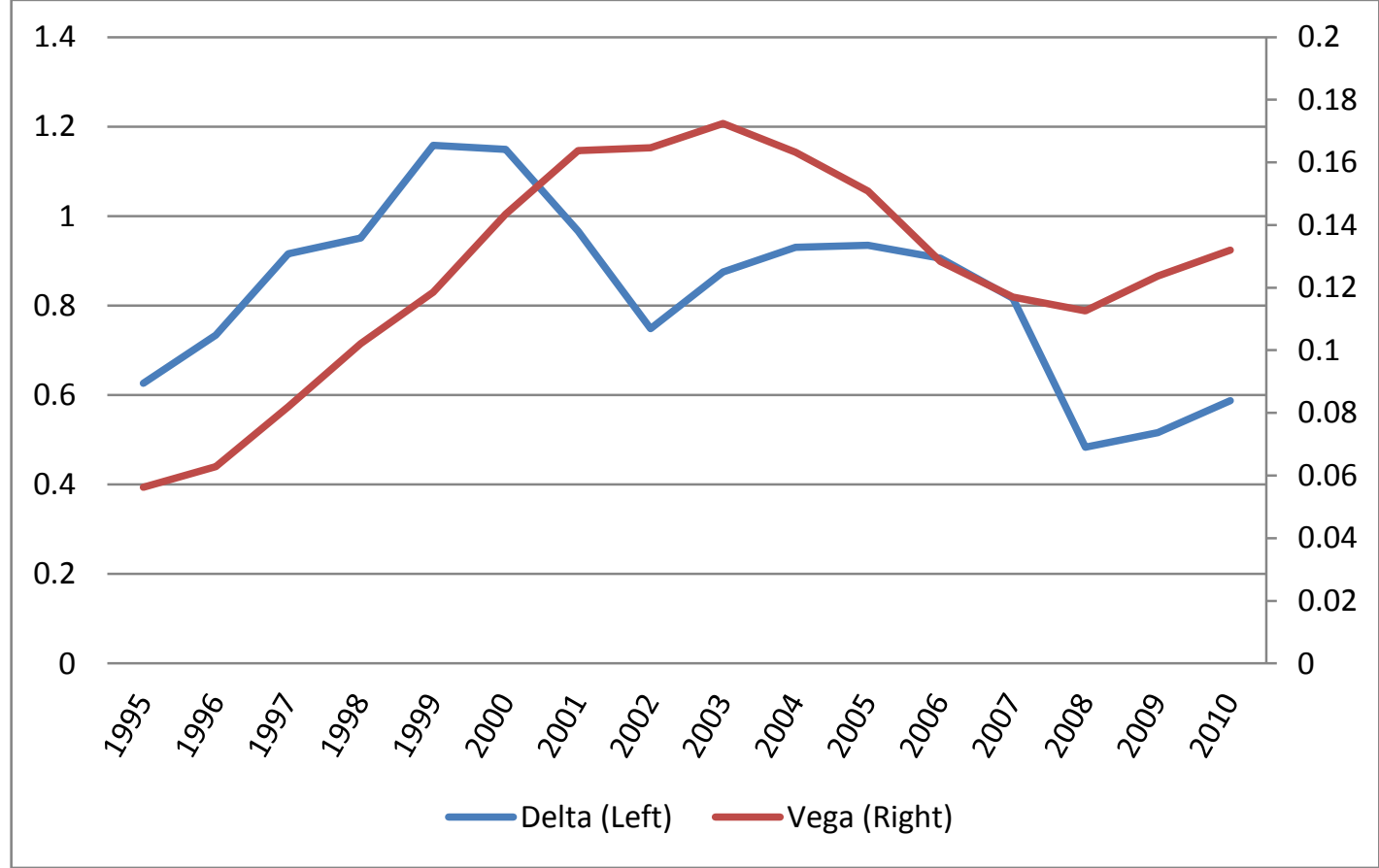

The figure presents the evolution of delta and vega for the universe of US publicly listed firms with data on ExecuComp over the period 1996-2010. Delta and Vega are in US million. The scale for delta is on the left y-axis; the scale for vega is on the right $\mathrm{y}$-axis. Dollar values are stated in 2005 dollars using the World Bank's consumer price index deflator. 
Table 1

Descriptive Statistics on Acquisitions

\begin{tabular}{cccccc}
\hline Year & N & Public & Private & Completed & Relative Size \\
\hline $\mathbf{1 9 9 7}$ & 752 & 190 & 562 & 696 & $15.50 \%$ \\
$\mathbf{1 9 9 8}$ & 854 & 231 & 623 & 791 & $13.55 \%$ \\
$\mathbf{1 9 9 9}$ & 879 & 267 & 612 & 804 & $15.16 \%$ \\
$\mathbf{2 0 0 0}$ & 775 & 205 & 570 & 719 & $12.67 \%$ \\
$\mathbf{2 0 0 1}$ & 616 & 158 & 458 & 566 & $12.54 \%$ \\
$\mathbf{2 0 0 2}$ & 607 & 103 & 504 & 570 & $8.70 \%$ \\
$\mathbf{2 0 0 3}$ & 619 & 111 & 508 & 580 & $9.75 \%$ \\
$\mathbf{2 0 0 4}$ & 689 & 121 & 568 & 638 & $13.48 \%$ \\
$\mathbf{2 0 0 5}$ & 675 & 108 & 567 & 631 & $10.21 \%$ \\
$\mathbf{2 0 0 6}$ & 658 & 137 & 521 & 597 & $11.94 \%$ \\
$\mathbf{2 0 0 7}$ & 704 & 142 & 562 & 642 & $11.89 \%$ \\
$\mathbf{2 0 0 8}$ & 553 & 103 & 450 & 479 & $16.59 \%$ \\
$\mathbf{2 0 0 9}$ & 362 & 65 & 297 & 344 & $12.90 \%$ \\
$\mathbf{2 0 1 0}$ & 531 & 104 & 427 & 488 & $11.68 \%$ \\
$\mathbf{2 0 1 1}$ & 515 & 63 & 452 & 458 & $12.64 \%$ \\
& & & & & $12.70 \%$ \\
\hline
\end{tabular}

The table presents yearly descriptive statistics for a sample of acquisitions by US publicly listed bidding firms announced over the period between January 1, 1997 and December 31, 2011. N denotes the number of acquisition announcements by year. An acquisition is considered public (private) when the target firm is a publicly listed (private) company. An acquisition is considered completed when the offer is successful and the deal consummated. Relative size is the ratio between the deal value and the market capitalization of the acquiring firm 30 days prior to the acquisition announcement. 
Table 2

Descriptive Statistics on CEO Compensation and other Firm and CEO Characteristics

\begin{tabular}{|c|c|c|c|c|}
\hline Panel A: Compensation Variables & Mean & Median & Std. Dev & $\mathbf{N}$ \\
\hline Total Compensation $(\$ 1,000)$ & $4,744.81$ & $2,599.72$ & $6,134.97$ & 28,332 \\
\hline Cash Compensation $(\$ 1,000)$ & $1,265.87$ & 887.49 & $1,223.48$ & 28,332 \\
\hline Equity Compensation $(\$ 1,000)$ & $3,427.29$ & $1,472.09$ & $5,353.78$ & 28,332 \\
\hline Option Compensation $(\$ 1,000)$ & $2,311.24$ & 696.52 & $4,511.85$ & 19,063 \\
\hline CEO Wealth $(\$ 1,000)$ & $66,279.80$ & $12,655.06$ & $195,768.10$ & 26,772 \\
\hline Stock Portfolio (\$ 1,000) & $53,294.75$ & $6,387.14$ & $181,079.60$ & 26,820 \\
\hline Option Portfolio (\$ 1,000) & $11,120.13$ & $2,276.96$ & $24,882.47$ & 27,974 \\
\hline Delta $(\$ 1,000)$ & 842.01 & 234.40 & $2,096.95$ & 26,834 \\
\hline Vega $(\$ 1,000)$ & 130.27 & 46.65 & 227.16 & 28,332 \\
\hline Delta (EGL) & 36.89 & 7.26 & 126.49 & 26,834 \\
\hline Vega (EGL) & 2.78 & 1.79 & 3.40 & 28,332 \\
\hline \multicolumn{5}{|c|}{ Panel B: Firm and CEO Characteristics } \\
\hline Size $(\$ 1,000,000)$ & $4,387.03$ & $1,178.63$ & $9,140.71$ & 28,256 \\
\hline $\mathbf{B} / \mathbf{M}$ & 0.5392 & 0.4604 & 0.5296 & 24,358 \\
\hline Cash Reserves & 0.1456 & 0.0710 & 0.1742 & 28,262 \\
\hline Leverage & 0.2288 & 0.2068 & 0.1949 & 28,157 \\
\hline Cash Flows & 0.0704 & 0.0742 & 0.0907 & 28,270 \\
\hline Overconfidence & 0.4669 & 0.0000 & 0.4989 & 28,310 \\
\hline Female & 0.0201 & 0.0000 & 0.1404 & 28,332 \\
\hline CEO Tenure & 6.6935 & 5.0000 & 6.8983 & 26,943 \\
\hline Entrenchment Index & 2.4507 & 2.0000 & 1.3870 & 22,061 \\
\hline DCS & 0.0878 & 0.0000 & 0.2830 & 22,061 \\
\hline Independent Directors & 0.6870 & 0.7143 & 0.16926 & 19,645 \\
\hline CEO/Chairman & 0.5528 & 1.0000 & 0.4972 & 28,332 \\
\hline Board Size & 9.5131 & 9.0000 & 2.6902 & 19,645 \\
\hline Excess Return Volatility & 0.4243 & 0.3649 & 0.2337 & 27,397 \\
\hline EBITDA/Interest Expenses & 57.0343 & 8.4325 & 209.2367 & 22,956 \\
\hline CAPEX & 0.0518 & 0.0364 & 0.0532 & 27,171 \\
\hline
\end{tabular}

The table presents descriptive statistics on CEO compensation for the universe of US publicly listed firms with data on ExecuComp over the period 1996-2010. Panel A reports the mean, median and standard deviation for CEO compensation and wealth. Panel B reports statistics for firm and CEO characteristics used in the empirical analysis. See Appendix A for definitions of the variables. N denotes the number of observations. Dollar values are stated in 2005 dollars using the World Bank's consumer price index deflator. 
Table 3

Change in Bidder Risk

\begin{tabular}{|c|c|c|c|c|c|c|c|c|c|c|}
\hline & \multicolumn{2}{|c|}{ Pre Acquisition } & \multicolumn{2}{|c|}{ Acquisition Period } & \multicolumn{2}{|c|}{ Post Acquisition } & \multicolumn{2}{|c|}{ Acquisition Period-Pre Acquisition } & \multicolumn{2}{|c|}{$\underline{\text { Post Acquisition-Pre Acquisition }}$} \\
\hline & $\begin{array}{c}\text { Return } \\
\text { Volatility }\end{array}$ & $\begin{array}{c}\text { Excess Return } \\
\text { Volatility }\end{array}$ & $\begin{array}{c}\text { Return } \\
\text { Volatility }\end{array}$ & $\begin{array}{c}\text { Excess Return } \\
\text { Volatility }\end{array}$ & $\begin{array}{l}\text { Return } \\
\text { Volatility }\end{array}$ & $\begin{array}{c}\text { Excess Return } \\
\text { Volatility }\end{array}$ & $\begin{array}{c}\text { Return } \\
\text { Volatility }\end{array}$ & $\begin{array}{c}\text { Excess Return } \\
\text { Volatility }\end{array}$ & $\begin{array}{c}\text { Return } \\
\text { Volatility }\end{array}$ & $\begin{array}{c}\text { Excess Return } \\
\text { Volatility }\end{array}$ \\
\hline Mean & $2.6290 \%$ & $2.3545 \%$ & $2.7044 \%$ & $2.4100 \%$ & $2.7047 \%$ & $2.4107 \%$ & $0.0754 \% * * *$ & $0.0555 \% * * *$ & $0.0757 \% * * *$ & $0.0562 \% * * *$ \\
\hline Median & $2.2717 \%$ & $2.0216 \%$ & $2.3022 \%$ & $2.0405 \%$ & $2.2973 \%$ & $2.0376 \%$ & $0.0085 \% * * *$ & $0.0140 \% * * *$ & $0.0057 \% * * *$ & $0.0142 \% * * *$ \\
\hline $\mathbf{N}$ & 9,592 & 9,592 & 9,592 & 9,592 & 9,592 & 9,592 & 9,592 & 9,592 & 9,592 & 9,592 \\
\hline
\end{tabular}

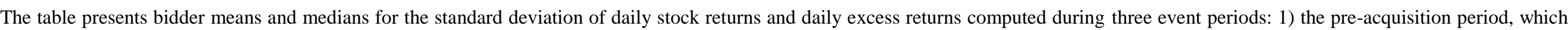

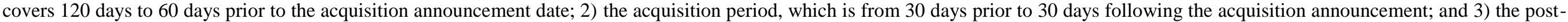

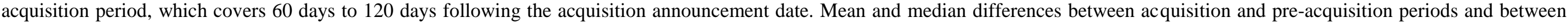

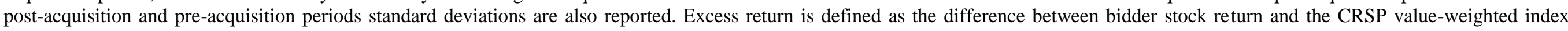

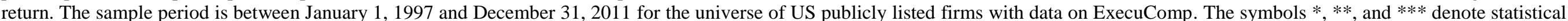

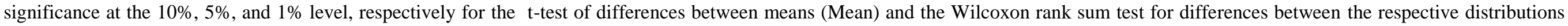
(Median). $\mathrm{N}$ denotes the number of observations. 
Table 4

Acquisition Investments and Risk-Taking Incentives

\begin{tabular}{|c|c|c|c|c|}
\hline & \multicolumn{2}{|c|}{ All Acquisition Investments (Tobit) } & \multicolumn{2}{|c|}{ All Acquisitions (Probit) } \\
\hline & $(\mathbf{1})$ & $(2)$ & (3) & (4) \\
\hline Constant & $\begin{array}{c}-0.9189 * * * \\
{[0.2013]}\end{array}$ & $\begin{array}{c}-0.9624 * * * \\
{[0.2313]}\end{array}$ & $\begin{array}{c}-1.5888 * * * \\
{[0.3411]}\end{array}$ & $\begin{array}{c}-1.7090 * * * \\
{[0.3838]}\end{array}$ \\
\hline Vega & $\begin{array}{c}0.1743 * * * \\
{[0.0429]}\end{array}$ & $\begin{array}{c}0.1482 * * * \\
{[0.0431]}\end{array}$ & $\begin{array}{c}0.2535 * * * \\
{[0.0736]}\end{array}$ & $\begin{array}{c}0.2145 * * * \\
{[0.0750]}\end{array}$ \\
\hline Delta & $\begin{array}{c}0.0114 * * \\
{[0.0050]}\end{array}$ & $\begin{array}{c}0.0163 * * * \\
{[0.0053]}\end{array}$ & $\begin{array}{c}0.0104 \\
{[0.0075]}\end{array}$ & $\begin{array}{c}0.0160 * * \\
{[0.0080]}\end{array}$ \\
\hline Size & $\begin{array}{c}-0.0036 \\
{[0.0087]}\end{array}$ & $\begin{array}{c}-0.0067 \\
{[0.0089]}\end{array}$ & $\begin{array}{c}0.0637 * * * \\
{[0.0144]}\end{array}$ & $\begin{array}{c}0.0625^{* * *} * \\
{[0.0148]}\end{array}$ \\
\hline $\mathbf{B} / \mathbf{M}$ & $\begin{array}{c}-0.0751 * * * \\
{[0.0161]}\end{array}$ & $\begin{array}{c}-0.0695 * * * \\
{[0.0162]}\end{array}$ & $\begin{array}{c}-0.0966 * * * \\
{[0.0242]}\end{array}$ & $\begin{array}{c}-0.0905 * * * \\
{[0.0248]}\end{array}$ \\
\hline Cash Reserves & $\begin{array}{c}0.1571 * * \\
{[0.0630]}\end{array}$ & $\begin{array}{c}0.1398 * * \\
{[0.0636]}\end{array}$ & $\begin{array}{c}0.0508 \\
{[0.0949]}\end{array}$ & $\begin{array}{c}0.0389 \\
{[0.0979]}\end{array}$ \\
\hline Leverage & $\begin{array}{c}0.0126 \\
{[0.0527]}\end{array}$ & $\begin{array}{c}-0.0195 \\
{[0.0519]}\end{array}$ & $\begin{array}{l}-0.0894 \\
{[0.0799]}\end{array}$ & $\begin{array}{l}-0.1275 \\
{[0.0821]}\end{array}$ \\
\hline Cash Flows & $\begin{array}{c}0.3664 * * * \\
{[0.1099]}\end{array}$ & $\begin{array}{c}0.3818 * * * \\
{[0.1108]}\end{array}$ & $\begin{array}{c}0.8894 * * * \\
{[0.1509]}\end{array}$ & $\begin{array}{c}0.9080 * * * \\
{[0.1540]}\end{array}$ \\
\hline Overconfidence & $\begin{array}{c}0.0896 * * * \\
{[0.0153]}\end{array}$ & $\begin{array}{c}0.0902 * * * * \\
{[0.0153]}\end{array}$ & $\begin{array}{c}0.1240 * * * * \\
{[0.0238]}\end{array}$ & $\begin{array}{c}0.1289 * * * * \\
{[0.0242]}\end{array}$ \\
\hline Cash Compensation & $\begin{array}{c}0.0389 * * \\
{[0.0156]}\end{array}$ & $\begin{array}{c}0.0508 * * * \\
{[0.0159]}\end{array}$ & $\begin{array}{l}0.0477 * \\
{[0.0245]}\end{array}$ & $\begin{array}{l}0.0620 * * \\
{[0.0255]}\end{array}$ \\
\hline Female & & $\begin{array}{c}-0.005 \\
{[0.0687]}\end{array}$ & & $\begin{array}{c}-0.0528 \\
{[0.0952]}\end{array}$ \\
\hline CEO Tenure & & $\begin{array}{c}-0.0040 * * * \\
{[0.0012]}\end{array}$ & & $\begin{array}{l}-0.0031 \\
{[0.0019]}\end{array}$ \\
\hline Year \& Industry FE & yes & yes & yes & yes \\
\hline Pseudo $\mathbf{R}^{2}$ & 0.0564 & 0.0583 & 0.0611 & 0.0627 \\
\hline Observations & 23,101 & 22,219 & 23,101 & 22,219 \\
\hline
\end{tabular}

The table presents in specifications (1) and (2) the estimates of pooled tobit regressions with clustered standard errors at firm level where the dependent variable is the sum of the deal values of acquisition investments made in a given year scaled by sales in the previous year. Specifications (3) and (4) present the estimates of pooled probit regressions with clustered standard errors at firm level where the dependent variable takes the value of one if a firm made an acquisition in a given year, and zero otherwise. The sample period is between January 1, 1997 and December 31, 2011 for the universe of US publicly listed firms with data on ExecuComp. See Appendix A for definitions of the variables. All independent variables are lagged with respect to the dependent variable. All variables are winsorized at the $1 \%$ on both tails, with the exception of binary variables. Dollar values are stated in 2005 dollars using the World Bank's consumer price index deflator. Year and industry fixed effects, whose coefficients are suppressed, are based on calendar year and Fama-French 49 industry classification dummies, respectively. Heteroskedasticity-robust clustered standard errors at firm level are reported in brackets. The symbols $*$, **, and $* * *$ denote statistical significance at the $10 \%, 5 \%$, and $1 \%$ level, respectively. 
Table 5

Acquisition Investments and Risk-Taking Incentives: The Role of Corporate Governance

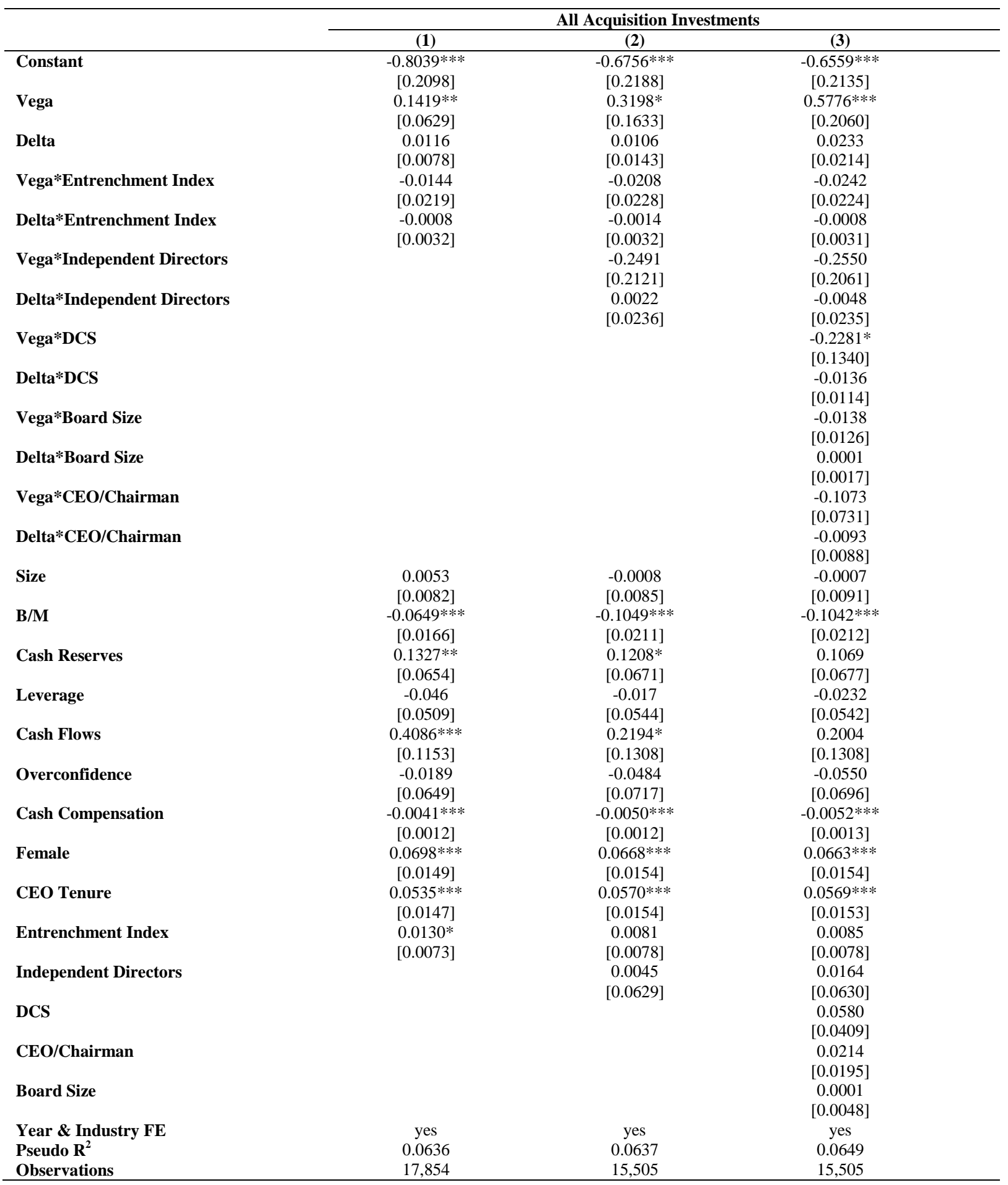

The table presents the estimates of pooled tobit regressions with clustered standard errors at firm level where the dependent variable is the sum of the deal values of all acquisition investments made in a given year scaled by sales in the previous year. The sample period is between January 1, 1997 and December 31, 2011 for the universe of US publicly listed firms with data on ExecuComp. See Appendix A for definitions of the variables. All independent variables are lagged with respect to the dependent variable. All variables are winsorized at the $1 \%$ on both tails, with the exception of binary variables. Dollar values are stated in 2005 dollars using the World Bank's consumer price index deflator. Year and industry fixed effects, whose coefficients are suppressed, are based on calendar year and Fama-French 49 industry classification dummies, respectively. Heteroskedasticity-robust clustered standard errors at firm level are reported in brackets. The symbols *,**, and *** denote statistical significance at the $10 \%$, $5 \%$, and $1 \%$ level, respectively. 
Table 6

CAPEX and Risk-Taking Incentives

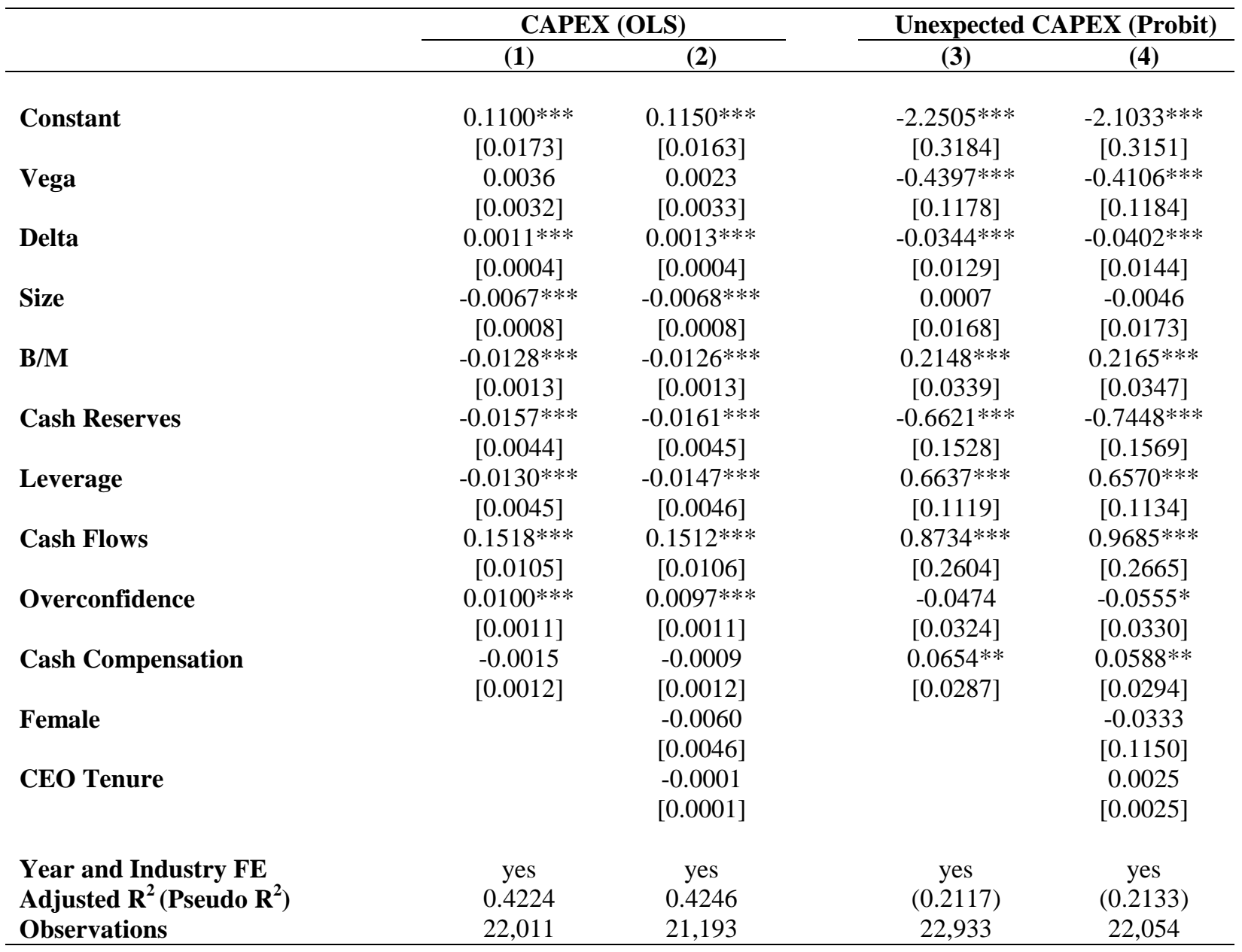

The table presents in specifications (1) and (2) the estimates of pooled OLS regressions with clustered standard errors at firm level where the dependent variable is the CAPEX investment scaled by total assets. In specifications (3) and (4) we present the estimates of pooled probit regressions where the dependent variable is the binary variable of unexpected CAPEX investment. The sample period is between January 1, 1997 and December 31, 2011 for the universe of US publicly listed firms with data on ExecuComp. See Appendix A for definitions of the variables. All independent variables are lagged with respect to the dependent variable. All variables are winsorized at the $1 \%$ on both tails, with the exception of binary variables. Dollar values are stated in 2005 dollars using the World Bank's consumer price index deflator. Year and industry fixed effects, whose coefficients are suppressed, are based on calendar year and Fama-French 49 industry classification dummies, respectively. Heteroskedasticity-robust clustered standard errors at firm level are reported in brackets. The symbols *, **, and *** denote statistical significance at the $10 \%, 5 \%$, and $1 \%$ level, respectively. 
Table 7

Predicted and Residual Vega and Delta

\begin{tabular}{|c|c|c|}
\hline & All A & ments \\
\hline & (1) & (2) \\
\hline Constant & -0.2784 & $1.1297 * * *$ \\
\hline & {$[0.2636]$} & {$[0.4187]$} \\
\hline Predicted Vega & $0.8317 * * *$ & $2.5934 * * *$ \\
\hline & {$[0.2030]$} & {$[0.5500]$} \\
\hline Residual Vega & & $-0.2469 *$ \\
\hline & & [0.1298] \\
\hline Predicted Delta & $0.0674 * * *$ & $0.1129 *$ \\
\hline & {$[0.0209]$} & {$[0.0633]$} \\
\hline Residual Delta & & $-0.0531 * * *$ \\
\hline & & {$[0.0136]$} \\
\hline Size & $-0.0707 * * *$ & $-0.2016 * * *$ \\
\hline & {$[0.0166]$} & {$[0.0357]$} \\
\hline $\mathbf{B} / \mathbf{M}$ & -0.0288 & 0.0298 \\
\hline & {$[0.0190]$} & [0.0299] \\
\hline Cash Reserves & $0.2917 * * *$ & $0.3104 * * *$ \\
\hline & {$[0.0726]$} & {$[0.0719]$} \\
\hline Leverage & 0.0545 & $0.2271 * * *$ \\
\hline & {$[0.0582]$} & {$[0.0855]$} \\
\hline Cash Flows & $0.7341 * * *$ & $0.9876 * * *$ \\
\hline & {$[0.1221]$} & {$[0.1388]$} \\
\hline Overconfidence & $0.0725 * * *$ & $0.0709 * * *$ \\
\hline & {$[0.0155]$} & {$[0.0153]$} \\
\hline Cash Compensation & -0.0043 & $-0.1310 * * *$ \\
\hline & {$[0.0215]$} & {$[0.0377]$} \\
\hline Female & -0.0005 & 0.0009 \\
\hline & {$[0.0721]$} & {$[0.0722]$} \\
\hline CEO Tenure & $-0.0079 * * *$ & $-0.0139 * * *$ \\
\hline & {$[0.0020]$} & {$[0.0044]$} \\
\hline Year \& Industry FE & yes & yes \\
\hline Pseudo $\mathbf{R}^{2}$ & 0.0660 & 0.0685 \\
\hline Observations & 18,271 & 18,271 \\
\hline
\end{tabular}

The table presents the estimates of pooled tobit regressions with clustered standard errors at firm level where the dependent variable is the sum of the deal values of all acquisition investments made in a given year scaled by sales in the previous year. The sample period is between January 1, 1997 and December 31, 2011 for the universe of US publicly listed firms with data on ExecuComp. Predicted and residual lagged vega and delta are the predicted values and residuals from regressions of vega and delta on endogenous and control variables shown in Table IV. See Appendix A for definitions of the variables. All independent variables are lagged with respect to the dependent variable. All variables are winsorized at the $1 \%$ on both tails, with the exception of binary variables. Dollar values are stated in 2005 dollars using the World Bank's consumer price index deflator. Year and industry fixed effects, whose coefficients are suppressed, are based on calendar year and Fama-French 49 industry classification dummies, respectively. Heteroskedasticity-robust clustered standard errors at firm level are reported in brackets. The symbols $*, * *$, and $* * *$ denote statistical significance at the $10 \%, 5 \%$, and $1 \%$ level, respectively. 
Table 8

Systems of Simultaneous Equations

\begin{tabular}{|c|c|c|c|}
\hline & $\begin{array}{c}\text { All Acquisition Investments } \\
\text { (1) }\end{array}$ & $\begin{array}{c}\text { Vega } \\
(2) \\
\end{array}$ & $\begin{array}{c}\text { Delta } \\
(3) \\
\end{array}$ \\
\hline Constant & $\begin{array}{c}0.7218 * * * \\
{[0.0264]}\end{array}$ & $\begin{array}{c}-0.7485 * * * \\
{[0.0169]}\end{array}$ & $\begin{array}{c}-3.7785 * * * \\
{[0.1421]}\end{array}$ \\
\hline Acquisition Investments & & $\begin{array}{c}0.3909 * * * \\
{[0.0299]}\end{array}$ & $\begin{array}{c}7.4749 * * * \\
{[0.2846]}\end{array}$ \\
\hline Vega & $\begin{array}{c}0.6506 * * * \\
{[0.0303]}\end{array}$ & & $\begin{array}{c}-0.9024 * * * \\
{[0.1936]}\end{array}$ \\
\hline Delta & $\begin{array}{c}0.0682 * * * \\
{[0.0040]}\end{array}$ & $\begin{array}{c}0.0122 * * * \\
{[0.0021]}\end{array}$ & \\
\hline Size & $\begin{array}{c}-0.0811 * * * \\
{[0.0025]}\end{array}$ & $\begin{array}{c}0.0603 * * * \\
{[0.0016]}\end{array}$ & $\begin{array}{c}0.5595 * * * \\
{[0.0200]}\end{array}$ \\
\hline $\mathbf{B} / \mathbf{M}$ & $\begin{array}{c}0.0438 * * * \\
{[0.0042]}\end{array}$ & $\begin{array}{c}-0.0264 * * * \\
{[0.0030]}\end{array}$ & $\begin{array}{c}-0.3959 * * * \\
{[0.0325]}\end{array}$ \\
\hline Cash Reserves & $\begin{array}{l}-0.0067 \\
{[0.0121]}\end{array}$ & & \\
\hline Leverage & $\begin{array}{c}0.1518 * * * \\
{[0.0115]}\end{array}$ & $\begin{array}{c}-0.0680 * * * \\
{[0.0088]}\end{array}$ & $\begin{array}{c}-1.3307 * * * \\
{[0.0892]}\end{array}$ \\
\hline Cash Flows & $\begin{array}{l}0.0474 * * \\
{[0.0205]}\end{array}$ & $\begin{array}{c}-0.1099 * * * \\
{[0.0198]}\end{array}$ & \\
\hline Overconfidence & $\begin{array}{c}0.0154 * * * \\
{[0.0047]}\end{array}$ & & \\
\hline Cash Compensation & $\begin{array}{c}-0.0335 * * * \\
{[0.0033]}\end{array}$ & $\begin{array}{c}0.0658 * * * \\
{[0.0026]}\end{array}$ & \\
\hline Female & $\begin{array}{c}-0.0059 * * * \\
{[0.0004]}\end{array}$ & & $\begin{array}{c}0.0760 * * * \\
{[0.0023]}\end{array}$ \\
\hline CEO Tenure & $\begin{array}{c}0.0035 \\
{[0.0101]}\end{array}$ & & \\
\hline CAPEX & & $\begin{array}{c}-0.0769 * * * \\
{[0.0262]}\end{array}$ & $\begin{array}{l}0.4598 * \\
{[0.2435]}\end{array}$ \\
\hline Annualized Excess Ret. Volatility & & $\begin{array}{l}-0.0090 \\
{[0.0066]}\end{array}$ & $\begin{array}{c}0.1696 * * * \\
{[0.0616]}\end{array}$ \\
\hline EBITDA/Interest Expenses & & $\begin{array}{l}0.0139 * * \\
{[0.0066]}\end{array}$ & \\
\hline $\begin{array}{l}\text { Year \& Industry FE } \\
\text { Observations }\end{array}$ & $\begin{array}{c}\text { yes } \\
18,271\end{array}$ & $\begin{array}{c}\text { yes } \\
18,271\end{array}$ & $\begin{array}{c}\text { yes } \\
18,271\end{array}$ \\
\hline
\end{tabular}

The table presents the estimates of systems of simultaneous equations running 3SLS regressions where the dependent variable is the sum of the deal values of all acquisition investments made in a given year scaled by sales in the previous year and the jointly determined variables are the acquisition investments, vega and delta. The sample period is between January 1, 1997 and December 31, 2011 for the universe of US publicly listed firms with data on ExecuComp. See Appendix A for definitions of the variables. All independent variables are contemporaneous. All variables are winsorized at the $1 \%$ on both tails, with the exception of binary variables. Dollar values are stated in 2005 dollars using the World Bank's consumer price index deflator. Year and industry fixed effects, whose coefficients are suppressed, are based on calendar year and FamaFrench 49 industry classification dummies, respectively. Heteroskedasticity-robust clustered standard errors at firm level are reported in brackets. The symbols *,**, and *** denote statistical significance at the $10 \%, 5 \%$, and $1 \%$ level, respectively. 
Table 9

Natural Experiment - Crisis Period

\begin{tabular}{|c|c|c|c|}
\hline & $\begin{array}{c}\text { All Acquisition } \\
\text { Investments in } \\
2009 \\
\end{array}$ & $\begin{array}{c}\text { All Acquisition } \\
\text { Investments in } \\
2009-2010 \\
\end{array}$ & $\begin{array}{c}\text { Instrumental } \\
\text { Variable } \\
\text { Regression } \\
\end{array}$ \\
\hline & (1) & $(2)$ & (3) \\
\hline Constant & $\begin{array}{c}-3.4170 * * * \\
{[0.0152]}\end{array}$ & $\begin{array}{c}-0.9774 * * \\
{[0.4371]}\end{array}$ & $\begin{array}{c}-0.9955 * * * \\
{[0.2931]}\end{array}$ \\
\hline Vega & $\begin{array}{c}0.2618 * * * \\
{[0.0179]}\end{array}$ & $\begin{array}{c}0.2642 * * \\
{[0.1323]}\end{array}$ & \\
\hline Delta & $\begin{array}{c}0.0175 * * * \\
{[0.0017]}\end{array}$ & $\begin{array}{l}0.0338^{*} \\
{[0.0205]}\end{array}$ & \\
\hline Instrumented Vega & & & $\begin{array}{c}0.1772 * * \\
{[0.0781]}\end{array}$ \\
\hline Instrumented Delta & & & $\begin{array}{l}0.0214 * * \\
{[0.0098]}\end{array}$ \\
\hline Size & $\begin{array}{c}0.0210 * * * \\
{[0.0019]}\end{array}$ & $\begin{array}{c}-0.0060 \\
{[0.0229]}\end{array}$ & $\begin{array}{c}0.0099 \\
{[0.0150]}\end{array}$ \\
\hline $\mathbf{B} / \mathbf{M}$ & $\begin{array}{l}-0.0148 * \\
{[0.0090]}\end{array}$ & $\begin{array}{c}-0.0381 \\
{[0.0340]}\end{array}$ & $\begin{array}{c}-0.0057 \\
{[0.0245]}\end{array}$ \\
\hline Cash Reserves & $\begin{array}{c}0.0800 * * \\
{[0.0341]}\end{array}$ & $\begin{array}{c}-0.0722 \\
{[0.2038]}\end{array}$ & $\begin{array}{c}-0.0179 \\
{[0.1302]}\end{array}$ \\
\hline Leverage & $\begin{array}{c}-0.3092 * * * \\
{[0.0323]}\end{array}$ & $\begin{array}{l}-0.2216^{*} \\
{[0.1306]}\end{array}$ & $\begin{array}{l}-0.1488 * \\
{[0.0895]}\end{array}$ \\
\hline Cash Flows & $\begin{array}{c}0.4170 * * * \\
{[0.0599]}\end{array}$ & $\begin{array}{c}0.7184 * * \\
{[0.3301]}\end{array}$ & $\begin{array}{c}0.4815 * * \\
{[0.2161]}\end{array}$ \\
\hline Overconfidence & $\begin{array}{c}0.0642 * * * \\
{[0.0108]}\end{array}$ & $\begin{array}{c}0.0573 \\
{[0.0525]}\end{array}$ & $\begin{array}{c}0.0482 \\
{[0.0337]}\end{array}$ \\
\hline Cash Compensation & $\begin{array}{c}0.0133 * * * \\
{[0.0023]}\end{array}$ & $\begin{array}{l}0.0960^{*} \\
{[0.0563]}\end{array}$ & $\begin{array}{c}0.0687 * * \\
{[0.0341]}\end{array}$ \\
\hline Female & $\begin{array}{c}0.0921 * * * \\
{[0.0109]}\end{array}$ & $\begin{array}{c}0.0338 \\
{[0.2005]}\end{array}$ & $\begin{array}{c}0.0045 \\
{[0.1063]}\end{array}$ \\
\hline CEO Tenure & $\begin{array}{c}-0.0066^{* * *} * \\
{[0.0009]}\end{array}$ & $\begin{array}{l}-0.0074 * \\
{[0.0039]}\end{array}$ & $\begin{array}{c}-0.0051 * * \\
{[0.0024]}\end{array}$ \\
\hline $\begin{array}{l}\text { Year \& Industry FE } \\
\text { Pseudo } \mathbf{R}^{2} \\
\text { Observations }\end{array}$ & $\begin{array}{c}\text { yes } \\
0.1559 \\
1,606\end{array}$ & $\begin{array}{c}\text { yes } \\
0.1049 \\
1,559 \\
\end{array}$ & $\begin{array}{c}\text { yes } \\
0.1053 \\
3,098 \\
\end{array}$ \\
\hline
\end{tabular}

The table presents in specifications (1) and (2) the estimates of pooled tobit regressions with clustered standard errors at firm level where the dependent variable is the sum of the deal values of all acquisition investments, made in year 2009 (specification (1)) and in years 2009 and 2010 (specification (2)), scaled by sales in the previous year. Specification (3) reports the estimates of the second stage of an instrumental variable regression model for the period where the dependent variable is the sum of the deal values of all acquisition investments in year $t$, where $t$ includes 2009 and 2010. The instrumented vega (delta) is obtained in the first stage of the model where we regress vega (delta) on year dummies and the interaction between year dummies and vega (delta) in 2007 . The first stage regression includes firm fixed effects. See Appendix A for definitions of the variables. For specifications (1) and (2) all independent variables are for the year 2008. All variables are winsorized at the $1 \%$ on both tails, with the exception of binary variables. Dollar values are stated in 2005 dollars using the World Bank's consumer price index deflator. Year and industry fixed effects, whose coefficients are suppressed, are based on calendar year and FamaFrench 49 industry classification dummies, respectively. Heteroskedasticity-robust clustered standard errors at firm level are reported in brackets. The symbols *,**, and *** denote statistical significance at the $10 \%, 5 \%$, and $1 \%$ level, respectively. 
Table 10

Bidder 5-day CARs and Risk-Taking Incentives

\begin{tabular}{|c|c|c|c|}
\hline Panel A: All Acquisitions & (1) & (2) & (3) \\
\hline \multirow[t]{2}{*}{ Constant } & $0.0634 * * *$ & $0.0699 * * *$ & $0.0614 * * *$ \\
\hline & $\lceil 0.0202\rceil$ & $\lceil 0.0236\rceil$ & $\lceil 0.0238\rceil$ \\
\hline \multirow[t]{2}{*}{ Vega } & $0.0082 * * *$ & $0.0114 * * *$ & $0.0116 * * *$ \\
\hline & {$[0.0028]$} & [0.0037] & {$[0.0040]$} \\
\hline \multirow[t]{2}{*}{ Delta } & $0.0012 * * *$ & $0.0012 * * *$ & $0.0009 * *$ \\
\hline & $\lceil 0.0003\rceil$ & $\lceil 0.0004\rceil$ & $\lceil 0.0004\rceil$ \\
\hline \multirow{2}{*}{ Size } & $-0.0046 * * *$ & $-0.0052 * * *$ & $-0.0048 * * *$ \\
\hline & $\lceil 0.0007\rceil$ & $\lceil 0.0009\rceil$ & $\lceil 0.0009\rceil$ \\
\hline \multirow{2}{*}{$\mathbf{B} / \mathbf{M}$} & -0.0021 & -0.0047 & -0.0054 \\
\hline & $\lceil 0.0037\rceil$ & $\lceil 0.0049\rceil$ & $\lceil 0.0051\rceil$ \\
\hline \multirow{2}{*}{ Cash Reserves } & $-0.0138 * *$ & $-0.0148 *$ & $-0.0149 *$ \\
\hline & {$[0.0070]$} & {$[0.0081]$} & {$[0.0083]$} \\
\hline \multirow[t]{2}{*}{ Leverage } & -0.0030 & 0.0016 & -0.0001 \\
\hline & {$[0.0064]$} & {$[0.0077]$} & {$[0.0079]$} \\
\hline \multirow[t]{2}{*}{ Relative Size } & $-0.0103 *$ & $-0.0134 * *$ & $-0.0132 * *$ \\
\hline & $\lceil 0.0057\rceil$ & $\lceil 0.0063\rceil$ & $\lceil 0.0065\rceil$ \\
\hline \multirow[t]{2}{*}{ Diversifying } & 0.0025 & 0.0030 & 0.0035 \\
\hline & $\lceil 0.0018\rceil$ & $\lceil 0.0022\rceil$ & $\lceil 0.0022\rceil$ \\
\hline \multirow[t]{2}{*}{ Completed } & 0.0051 & 0.0053 & $0.0077 *$ \\
\hline & $\lceil 0.0032\rceil$ & $\lceil 0.0043\rceil$ & $\lceil 0.0043\rceil$ \\
\hline \multirow[t]{2}{*}{ Hostile } & -0.0023 & -0.0021 & -0.0017 \\
\hline & $\lceil 0.0072\rceil$ & $\lceil 0.0080\rceil$ & $\lceil 0.0080\rceil$ \\
\hline \multirow[t]{2}{*}{ Tender Offer } & 0.0187 & 0.0164 & 0.0168 \\
\hline & $\lceil 0.0116\rceil$ & $\lceil 0.0130\rceil$ & $\lceil 0.0129\rceil$ \\
\hline \multirow[t]{2}{*}{ Public } & $-0.0177 * * *$ & $-0.0172 * * *$ & $-0.0174 * * *$ \\
\hline & $\lceil 0.0023\rceil$ & $\lceil 0.0026\rceil$ & [0.0026] \\
\hline \multirow[t]{2}{*}{ Annualized Return Volatility } & -0.1798 & -0.0528 & -0.0326 \\
\hline & $\lceil 0.1097\rceil$ & $\lceil 0.1369\rceil$ & $\lceil 0.1406\rceil$ \\
\hline \multirow[t]{2}{*}{ Cash Flows } & 0.0191 & 0.0237 & 0.0251 \\
\hline & $\lceil 0.0146\rceil$ & $\lceil 0.0170\rceil$ & $\lceil 0.0176\rceil$ \\
\hline \multirow[t]{2}{*}{ Stock } & & $-0.0102 * * *$ & $-0.0105^{* * *}$ \\
\hline & & $\lceil 0.0038\rceil$ & $\lceil 0.0040\rceil$ \\
\hline \multirow[t]{2}{*}{ Female } & & & -0.0044 \\
\hline & & & $\lceil 0.0086\rceil$ \\
\hline CEO Tenure & & & $\begin{array}{c}-0.0001 \\
{[0.0002]}\end{array}$ \\
\hline \multirow[t]{2}{*}{ Overconfidence } & & & 0.0013 \\
\hline & & & $\lceil 0.0021\rceil$ \\
\hline Year and Industry FE & yes & yes & yes \\
\hline Adjusted $\mathbf{R}^{2}$ & 0.0279 & 0.0355 & 0.0356 \\
\hline Observations & 7,223 & 5,037 & 4,839 \\
\hline
\end{tabular}




\begin{tabular}{|c|c|c|c|}
\hline Panel B: Interaction with Public & (1) & (2) & (3) \\
\hline Constant & $\begin{array}{c}0.0631 * * * \\
{[0.0202]}\end{array}$ & $\begin{array}{c}0.0695 * * * \\
{[0.0236]}\end{array}$ & $\begin{array}{c}0.0613 * * \\
{[0.0238]}\end{array}$ \\
\hline \multirow[t]{2}{*}{ Vega } & $0.0074 * *$ & $0.0107 * *$ & $0.0103 * *$ \\
\hline & $\lceil 0.0032\rceil$ & $\lceil 0.0043\rceil$ & $\lceil 0.0046\rceil$ \\
\hline \multirow[t]{2}{*}{ Delta } & $0.0010 * * *$ & $0.0008 *$ & 0.0006 \\
\hline & $\lceil 0.0004\rceil$ & $\lceil 0.0005\rceil$ & $\lceil 0.0005\rceil$ \\
\hline \multirow[t]{2}{*}{ Vega*Public } & 0.0029 & 0.0017 & 0.0038 \\
\hline & $\lceil 0.0062\rceil$ & $\lceil 0.0069\rceil$ & $\lceil 0.0069\rceil$ \\
\hline \multirow[t]{2}{*}{ Delta*Public } & 0.0008 & 0.0009 & 0.0009 \\
\hline & {$[0.0005]$} & {$[0.0007]$} & {$[0.0007]$} \\
\hline \multirow[t]{2}{*}{ Size } & $-0.0046 * * *$ & $-0.0052 * * *$ & $-0.0047 * * *$ \\
\hline & [0.0007] & {$[0.0009]$} & {$[0.0010]$} \\
\hline \multirow[t]{2}{*}{$\mathbf{B} / \mathbf{M}$} & -0.0022 & -0.0048 & -0.0055 \\
\hline & $\lceil 0.0037\rceil$ & $\lceil 0.0049\rceil$ & $\lceil 0.0051\rceil$ \\
\hline \multirow[t]{2}{*}{ Cash Reserves } & $-0.0136^{*}$ & $-0.0145^{*}$ & $-0.0145^{*}$ \\
\hline & $\lceil 0.0070\rceil$ & $\lceil 0.0082\rceil$ & $\lceil 0.0083\rceil$ \\
\hline \multirow[t]{2}{*}{ Leverage } & -0.0029 & 0.0017 & -0.0001 \\
\hline & $\lceil 0.0064\rceil$ & $\lceil 0.0077\rceil$ & $\lceil 0.0079\rceil$ \\
\hline \multirow[t]{2}{*}{ Relative Size } & $-0.0098 *$ & $-0.0130 * *$ & $-0.0126^{*}$ \\
\hline & {$[0.0058]$} & {$[0.0064]$} & {$[0.0066]$} \\
\hline \multirow[t]{2}{*}{ Diversifying } & 0.0025 & 0.0030 & 0.0035 \\
\hline & $\lceil 0.0018\rceil$ & $\lceil 0.0022\rceil$ & $\lceil 0.0022\rceil$ \\
\hline \multirow[t]{2}{*}{ Completed } & 0.0051 & 0.0052 & $0.0076 *$ \\
\hline & $\lceil 0.0032\rceil$ & $\lceil 0.0043\rceil$ & $\lceil 0.0043\rceil$ \\
\hline \multirow[t]{2}{*}{ Hostile } & -0.0023 & -0.0022 & -0.0019 \\
\hline & $\lceil 0.0072\rceil$ & $\lceil 0.0079\rceil$ & $\lceil 0.0080\rceil$ \\
\hline \multirow{2}{*}{ Tender Offer } & 0.0185 & 0.0163 & 0.0166 \\
\hline & {$[0.0117]$} & {$[0.0130]$} & {$[0.0129]$} \\
\hline \multirow[t]{2}{*}{ Public } & $-0.0197 * * *$ & $-0.0191 * * *$ & $-0.0198 * * *$ \\
\hline & $\lceil 0.0031\rceil$ & $\lceil 0.0034\rceil$ & $\lceil 0.0035\rceil$ \\
\hline \multirow[t]{2}{*}{ Annualized Return Volatility } & $-0.1809^{*}$ & -0.0562 & -0.0363 \\
\hline & $\lceil 0.1098\rceil$ & $\lceil 0.1372\rceil$ & $\lceil 0.1410\rceil$ \\
\hline \multirow[t]{2}{*}{ Cash Flows } & 0.0193 & 0.024 & 0.0257 \\
\hline & $\lceil 0.0146\rceil$ & $\lceil 0.0170\rceil$ & $\lceil 0.0176\rceil$ \\
\hline \multirow[t]{2}{*}{ Stock } & & $-0.0101 * * *$ & $-0.0102 * * *$ \\
\hline & & $\lceil 0.0038\rceil$ & $\lceil 0.0040\rceil$ \\
\hline \multirow[t]{2}{*}{ Female } & & & -0.0041 \\
\hline & & & $\lceil 0.0085\rceil$ \\
\hline \multirow[t]{2}{*}{ CEO Tenure } & & & -0.0001 \\
\hline & & & $\lceil 0.0002\rceil$ \\
\hline \multirow[t]{2}{*}{ Overconfidence } & & & 0.0012 \\
\hline & & & $\lceil 0.0021\rceil$ \\
\hline Year and Industry FE & yes & yes & yes \\
\hline Adjusted $\mathbf{R}^{2}$ & 0.0279 & 0.0354 & 0.0357 \\
\hline Observations & 7,223 & 5,037 & 4,839 \\
\hline
\end{tabular}

The table presents in Panel A the estimates of pooled OLS regressions with clustered standard errors at firm level of bidder 5-day cumulative abnormal returns (CARs) over the event window $(-2,+2)$ around the acquisition announcement over the period between January 1, 1997 and December 31, 2011 on vega and other control characteristics for the universe of US publicly listed bidding firms with data on ExecuComp. Panel B includes interactions of vega and delta with public target firms. See Appendix A for definitions of the variables. All variables are winsorized at the $1 \%$ on both tails. Dollar values are stated in 2005 dollars using the World Bank's consumer price index deflator. Year and industry fixed effects, whose coefficients are suppressed, are based on calendar year and Fama-French 49 industry classification dummies, respectively. Heteroskedasticity-robust clustered standard errors at firm level are reported in brackets. The symbols *,**, and *** denote statistical significance at the $10 \%$, $5 \%$, and $1 \%$ level, respectively. 
Table 11

Acquisition Investments and Change in Risk-Taking Incentives

\begin{tabular}{|c|c|c|c|c|}
\hline & \multicolumn{2}{|c|}{ All Acquisition Investments (Tobit) } & \multicolumn{2}{|c|}{ All Acquisitions (Probit) } \\
\hline & (1) & $(2)$ & (3) & (4) \\
\hline Constant & $\begin{array}{c}-1.2298 * * * \\
{[0.1986]}\end{array}$ & $\begin{array}{c}-1.3026^{* * *} \\
{[0.2212]}\end{array}$ & $\begin{array}{c}-2.0968 * * * \\
{[0.3626]}\end{array}$ & $\begin{array}{c}-2.2323 * * * \\
{[0.4028]}\end{array}$ \\
\hline Change in Vega & $\begin{array}{c}0.0482 * * * \\
{[0.0129]}\end{array}$ & $\begin{array}{c}0.0509 * * * \\
{[0.0130]}\end{array}$ & $\begin{array}{c}0.0663 * * * \\
{[0.0211]}\end{array}$ & $\begin{array}{c}0.0708 * * * \\
{[0.0214]}\end{array}$ \\
\hline Change in Delta & $\begin{array}{c}0.0526 * * * \\
{[0.0138]}\end{array}$ & $\begin{array}{c}0.0495 * * * \\
{[0.0138]}\end{array}$ & $\begin{array}{c}0.0668 * * * \\
{[0.0221]}\end{array}$ & $\begin{array}{c}0.0651 * * * \\
{[0.0223]}\end{array}$ \\
\hline Size & $\begin{array}{l}0.0184 * * \\
{[0.0081]}\end{array}$ & $\begin{array}{l}0.0159 * \\
{[0.0081]}\end{array}$ & $\begin{array}{c}0.0954 * * * \\
{[0.0144]}\end{array}$ & $\begin{array}{c}0.0937 * * * \\
{[0.0146]}\end{array}$ \\
\hline $\mathbf{B} / \mathbf{M}$ & $\begin{array}{c}-0.0611 * * * \\
{[0.0165]}\end{array}$ & $\begin{array}{c}-0.0586 * * * \\
{[0.0166]}\end{array}$ & $\begin{array}{c}-0.0808 * * * \\
{[0.0262]}\end{array}$ & $\begin{array}{c}-0.0767 * * * \\
{[0.0267]}\end{array}$ \\
\hline Cash Reserves & $\begin{array}{c}0.1700 * * \\
{[0.0662]}\end{array}$ & $\begin{array}{c}0.1434 * * \\
{[0.0667]}\end{array}$ & $\begin{array}{c}0.0807 \\
{[0.1036]}\end{array}$ & $\begin{array}{c}0.043 \\
{[0.1056]}\end{array}$ \\
\hline Leverage & $\begin{array}{c}-0.0439 \\
{[0.0536]}\end{array}$ & $\begin{array}{c}-0.0641 \\
{[0.0529]}\end{array}$ & $\begin{array}{c}-0.1743 * * \\
{[0.0871]}\end{array}$ & $\begin{array}{c}-0.2012 * * \\
{[0.0886]}\end{array}$ \\
\hline Cash Flows & $\begin{array}{c}0.5396 * * * \\
{[0.1157]}\end{array}$ & $\begin{array}{c}0.5319 * * * \\
{[0.1164]}\end{array}$ & $\begin{array}{c}1.0820 * * * \\
{[0.1696]}\end{array}$ & $\begin{array}{c}1.0675^{* * * *} \\
{[0.1718]}\end{array}$ \\
\hline Overconfidence & $\begin{array}{c}0.0705 * * * \\
{[0.0154]}\end{array}$ & $\begin{array}{c}0.0720 * * * \\
{[0.0153]}\end{array}$ & $\begin{array}{c}0.1061 * * * \\
{[0.0256]}\end{array}$ & $\begin{array}{c}0.1116^{* * * *} \\
{[0.0259]}\end{array}$ \\
\hline Cash Compensation & $\begin{array}{c}0.0436 * * * \\
{[0.0162]}\end{array}$ & $\begin{array}{c}0.0519 * * * \\
{[0.0165]}\end{array}$ & $\begin{array}{c}0.0524 * * \\
{[0.0265]}\end{array}$ & $\begin{array}{c}0.0624 * * \\
{[0.0272]}\end{array}$ \\
\hline Female & & $\begin{array}{c}-0.0251 \\
{[0.0659]}\end{array}$ & & $\begin{array}{c}-0.0867 \\
{[0.1037]}\end{array}$ \\
\hline CEO Tenure & & $\begin{array}{c}-0.0017 \\
{[0.0012]}\end{array}$ & & $\begin{array}{l}-0.0005 \\
{[0.0020]}\end{array}$ \\
\hline $\begin{array}{l}\text { Year \& Industry FE } \\
\text { Pseudo } \mathbf{R}^{2} \\
\text { Observations }\end{array}$ & $\begin{array}{c}\text { yes } \\
0.0603 \\
19,469 \\
\end{array}$ & $\begin{array}{c}\text { yes } \\
0.062 \\
18,944 \\
\end{array}$ & $\begin{array}{c}\text { yes } \\
0.0653 \\
19,469 \\
\end{array}$ & $\begin{array}{c}\text { yes } \\
0.0667 \\
18,944 \\
\end{array}$ \\
\hline
\end{tabular}

The table presents in specifications (1) and (2) the estimates of pooled tobit regressions with clustered standard errors at firm level where the dependent variable is the sum of the deal values of acquisition investments made in a given year scaled by sales in the previous year. Specifications (3) and (4) present the estimates of pooled probit regressions with clustered standard errors at firm level where the dependent variable takes the value of one if a firm made an acquisition in a given year, and zero otherwise. The sample period is between January 1, 1997 and December 31, 2011 for the universe of US publicly listed firms with data on ExecuComp. See Appendix A for definitions of the variables. All independent variables are lagged with respect to the dependent variable. All variables are winsorized at the $1 \%$ on both tails, with the exception of binary variables. Dollar values are stated in 2005 dollars using the World Bank's consumer price index deflator. Year and industry fixed effects, whose coefficients are suppressed, are based on calendar year and Fama-French 49 industry classification dummies, respectively. Heteroskedasticity-robust clustered standard errors at firm level are reported in brackets. The symbols $*$, **, and $* * *$ denote statistical significance at the $10 \%, 5 \%$, and $1 \%$ level, respectively. 
Table 12

Public Acquisition Investments and Risk-Taking Incentives

\begin{tabular}{|c|c|c|c|c|}
\hline & \multicolumn{2}{|c|}{ Public Acquisition Investments (Tobit) } & \multicolumn{2}{|c|}{ Public Acquisitions (Probit) } \\
\hline & (1) & (2) & (3) & (4) \\
\hline \multirow[t]{2}{*}{ Constant } & $-3.3723 * * *$ & $-3.3652 * * *$ & $-3.6252 * * *$ & $-3.7032 * * *$ \\
\hline & {$[0.4217]$} & [0.4677] & {$[0.4659]$} & {$[0.5131]$} \\
\hline \multirow[t]{2}{*}{ Vega } & $0.1773 * *$ & $0.1436 *$ & $0.1854 * *$ & $0.1498 *$ \\
\hline & {$[0.0760]$} & {$[0.0772]$} & {$[0.0837]$} & {$[0.0862]$} \\
\hline \multirow[t]{2}{*}{ Delta } & 0.0069 & $0.0135^{*}$ & 0.0063 & 0.0120 \\
\hline & {$[0.0075]$} & {$[0.0075]$} & {$[0.0081]$} & {$[0.0080]$} \\
\hline \multirow[t]{2}{*}{ Size } & $0.1242 * * *$ & $0.1193 * * *$ & $0.1640 * * *$ & $0.1631 * * *$ \\
\hline & {$[0.0159]$} & {$[0.0164]$} & {$[0.0181]$} & {$[0.0188]$} \\
\hline \multirow[t]{2}{*}{$\mathbf{B} / \mathbf{M}$} & $-0.1149 * * *$ & $-0.1035 * * *$ & $-0.1077 * * *$ & $-0.0983 * * *$ \\
\hline & {$[0.0304]$} & {$[0.0308]$} & {$[0.0313]$} & {$[0.0323]$} \\
\hline \multirow[t]{2}{*}{ Cash Reserves } & $0.3262 * * *$ & $0.3132 * *$ & $0.2885 * *$ & $0.2854 * *$ \\
\hline & {$[0.1210]$} & {$[0.1220]$} & {$[0.1221]$} & {$[0.1255]$} \\
\hline \multirow[t]{2}{*}{ Leverage } & -0.1139 & -0.1452 & $-0.1943^{*}$ & $-0.2270 * *$ \\
\hline & {$[0.1063]$} & {$[0.1043]$} & {$[0.1078]$} & {$[0.1092]$} \\
\hline \multirow[t]{2}{*}{ Cash Flows } & $0.4475 * *$ & $0.5315^{* *}$ & $0.4350 * *$ & $0.5178 * *$ \\
\hline & {$[0.2093]$} & {$[0.2096]$} & [0.2094] & [0.2119] \\
\hline \multirow[t]{2}{*}{ Overconfidence } & $0.0572 *$ & $0.0544 *$ & $0.0611 *$ & $0.0600 *$ \\
\hline & {$[0.0320]$} & {$[0.0322]$} & {$[0.0327]$} & {$[0.0334]$} \\
\hline \multirow[t]{2}{*}{ Cash Compensation } & $0.0891 * * *$ & $0.1016^{* * *}$ & $0.0853 * *$ & $0.0999 * * *$ \\
\hline & {$[0.0315]$} & {$[0.0326]$} & {$[0.0345]$} & {$[0.0361]$} \\
\hline \multirow[t]{2}{*}{ Female } & & -0.0441 & & -0.0703 \\
\hline & & {$[0.1275]$} & & {$[0.1317]$} \\
\hline \multirow{2}{*}{ CEO Tenure } & & $-0.0052 * *$ & & -0.0037 \\
\hline & & {$[0.0025]$} & & {$[0.0026]$} \\
\hline Year \& Industry FE & yes & yes & yes & yes \\
\hline Pseudo $\mathbf{R}^{2}$ & 0.0808 & 0.0846 & 0.0943 & 0.0984 \\
\hline Observations & 23,101 & 22,219 & 22,890 & 22,009 \\
\hline
\end{tabular}

The table presents in specifications (1) and (2) the estimates of pooled tobit regressions with clustered standard errors at firm level where the dependent variable is the sum of the deal values of public acquisition investments made in a given year scaled by sales in the previous year. Specifications (3) and (4) present the estimates of pooled probit regressions with clustered standard errors at firm level where the dependent variable takes the value of one if a firm made a public acquisition in a given year, and zero otherwise. The sample period is between January 1, 1997 and December 31, 2011 for the universe of US publicly listed firms with data on ExecuComp. See Appendix A for definitions of the variables. All independent variables are lagged with respect to the dependent variable. All variables are winsorized at the $1 \%$ on both tails. Dollar values are stated in 2005 dollars using the World Bank's consumer price index deflator. Year and industry fixed effects, whose coefficients are suppressed, are based on calendar year and Fama-French 49 industry classification dummies, respectively. Heteroskedasticity-robust clustered standard errors at firm level are reported in brackets. The symbols *, **, and *** denote statistical significance at the $10 \%, 5 \%$, and $1 \%$ level, respectively. 
Table 13

Acquisition Investments, Bidder 5-day CARs and Risk-Taking Incentives Using the EGL Measure

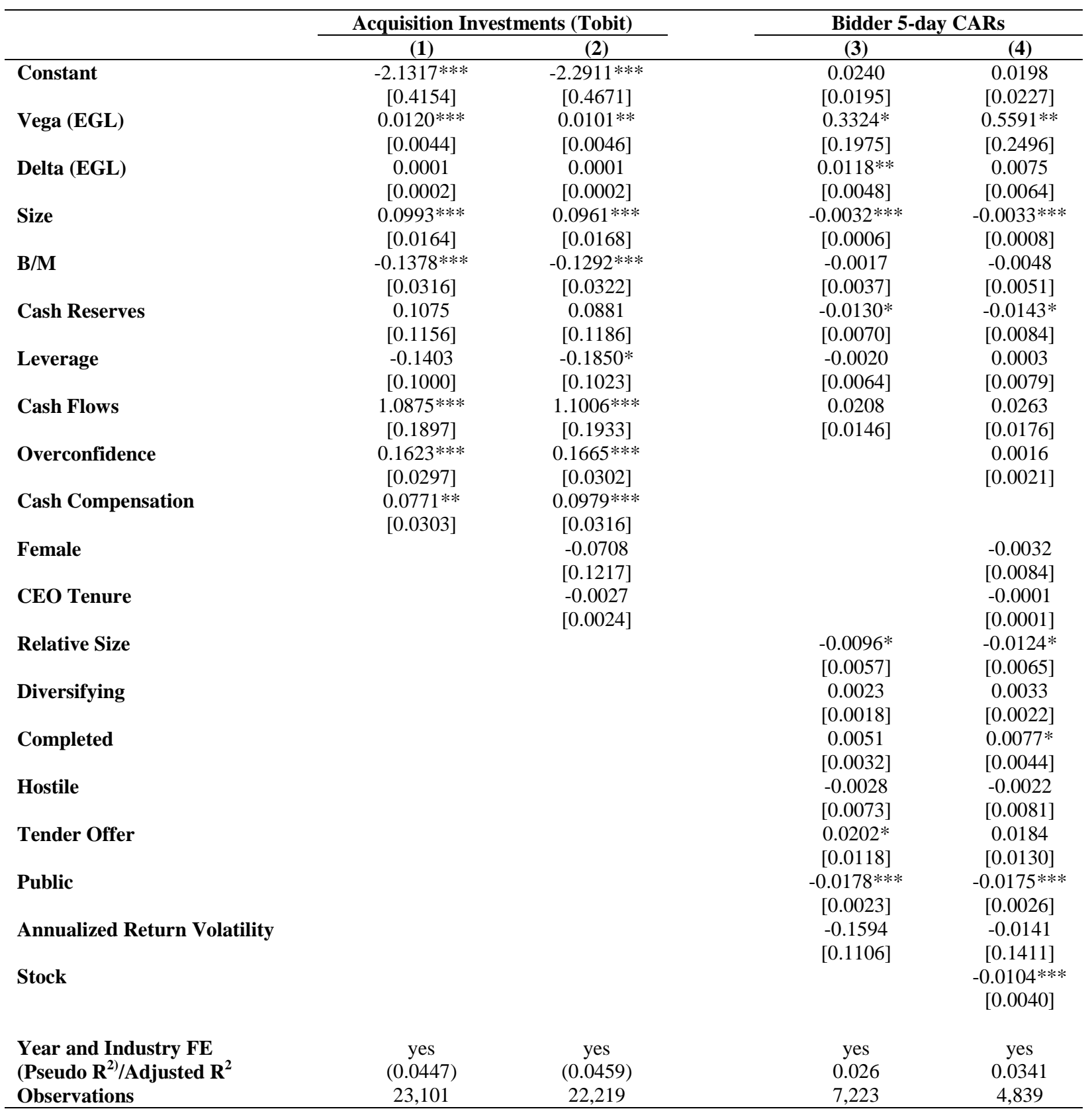

The table presents in specifications (1) and (2) the estimates of pooled tobit regressions with clustered standard errors at firm level where the dependent variable is the sum of the deal values of acquisition investments made in a given year scaled by sales in the previous year. In specifications (3) and (4) we present the estimates of pooled OLS regressions with clustered standard errors of the bidder 5-day cumulative abnormal returns (CARs) over the event window $(-2,+2)$ around the acquisition announcement on vega (EGL) and other control characteristics. Delta (EGL) and Vega (EGL) are computed following Edmans, Gabaix, and Landier (2009). The sample period is between January 1, 1997 and December 31, 2011 for the universe of US publicly listed firms with data on ExecuComp. See Appendix A for definitions of the variables. All independent variables are lagged with respect to the dependent variable. All variables are winsorized at the $1 \%$ on both tails, with the exception of binary variables. Dollar values are stated in 2005 dollars using the World Bank's consumer price index deflator. Year and industry fixed effects, whose coefficients are suppressed, are based on calendar year and Fama-French 49 industry classification dummies, respectively. Heteroskedasticity-robust clustered standard errors at firm level are reported in brackets. The symbols $*, * *$, and $* * *$ denote statistical significance at the $10 \%, 5 \%$, and $1 \%$ level, respectively. 